\title{
APPRAISAL OF THE EFFECT OF HUMIDITY ON TRIAXIAL COMPRESSIVE STRENGTH OF MARL MATERIAL BY NUMERICAL MODELING
}

\author{
Ercan EMIR $^{1) *}$ and Sunay BEYHAN ${ }^{2)}$ \\ 1) Department of Mining Engineering, Engineering Faculty, Eskişehir Osmangazi University, Eskişehir 26480, Turkey \\ ${ }^{2)}$ Department of Mining Engineering, Engineering Faculty, Dumlupinar University, Kütahya 43000 , Turkey \\ *Corresponding author's e-mail: eemir@ogu.edu.tr
}

\begin{tabular}{l} 
ARTICLE INFO \\
\hline Article history: \\
Received 17 March 2015 \\
Accepted 10 August 2015 \\
Available online 8 October 2015 \\
\hline
\end{tabular}

\section{Keywords:}

Atmospheric moisture absorption Humidity effect

Marl

Numerical model analysis

Triaxial compressive strength

\begin{abstract}
When it's essential to conduct intact rock strength tests on saturated samples to be representative of rock mass, clay bearing rocks such as marl which might present water sensitive behavior should be carefully inspected. In the following water table study, rock samples of Tunçbilek region that tend to fracture were alternatively conditioned in a climate cabin. According to the underground mine weather information taken from Tunçbilek region, triaxial compression tests were performed on oven dried marl samples and conditioned in $60 \%$ Relative Humidity (RH), $80 \% \mathrm{RH}$ and $90 \% \mathrm{RH}$ at $17.6{ }^{\circ} \mathrm{C}$. Calculated values of Mohr-Coulomb and Hoek-Brown failure criteria parameters depending on triaxial test results showed inverse change which does not let evaluate rock material strength. To achieve this goal, numerical modeling analyses were used. This allowed evaluating of intact rock triaxial strength by the effect of intact rock properties on the behavior of rock mass. Finally; it was found that moisture decreased the strength of marl rock material, and conditioning by moisture diffusion is an appropriate procedure for evaluating water sensitive rocks such as marl.
\end{abstract}

\section{INTRODUCTION}

Tunçbilek is one of the important coal basins in Turkey and marl is the main rock of this region. While the open pit reserves are being significantly reduced, production will continue from the underground mines in Tunçbilek region. Considering present and further underground mining projects for this region, intact rock properties of marl can be essential for each engineering operations in advance.

According to the International Society for Rock Mechanics (ISRM) suggested methods for the intact rock strength tests (1978a, 1978b, 1979 and 1983), it was emphasized to let specimens be stored for no longer than 30 days, in such a way as to preserve, as far as possible, the natural water content until the time of specimen preparation. Following preparation process, the specimens could be stored prior to testing for 5-6 days in an environment of $20^{\circ} \mathrm{C}+2{ }^{\circ} \mathrm{C}$ and $50 \%+5 \%$ humidity. It was recognized that in some cases for some materials it could be desired to test specimens in other moisture conditions, for example, saturated or oven dried at $105^{\circ} \mathrm{C}$. According to the ISRM suggested methods for the argillaceous swelling rocks (1989, Madsen, 1999), samples have to be protected from frost and extreme heat at all times during sampling and transportation. Sample temperature is to remain in the range of $5-30{ }^{\circ} \mathrm{C}$. If long-term storage is necessary, humidity in the storage room should have been so as to minimize any moisture gain or loss of the samples. Various researches pointed out that strength tests on rock materials should be performed on samples having in situ water content; otherwise, the results of it could be influenced (Burshtein, 1969; Van Eeckhout and Peng, 1975; Lin and Hung, 1982; Kramadibrata et al., 2000).

The literature involves various studies on the effect of water content on rock material strength. While some of these studies researched the effect of water on Uniaxial Compressive Strength (UCS) (Barefield and Shakoor, 2006; Shakoor and Barefield, 2009), a great majority researched the effect of water on both UCS and deformability (Hawkins and McConnell, 1992; Vásárhelyi, 2003; Vásárhelyi and Ván, 2006; Kwaśniewski and Rodriguez-Oitabén, 2009; Yilmaz, 2010). These studies state that water content decreased UCS of rock material and increased its deformation.

Triaxial compression test is generally used to determine the intact rock properties required for underground mining designs. Intact rock properties are also necessary to determine the rock mass behavior before any mining project. The literature involves a small number of studies that reveal the effect of moisture based on this test (Lin and Hung, 1982; Kramadibrata et al., 2000; Sachpazis, 2004; Li et al., 2005; Ergüler, 2007). Lin and Hung (1982) studied the influence of moisture contents of some sedimentary rocks in Taiwan, and found that not only the cohesion but also internal friction angle of mudstones and shales decreased very much with 
a slight increase of moisture content. They accounted for this moisture dependency of strength as lubricating effects of water on clay minerals in rock, and dissolution of cementing materials in rock. Kramadibrata et al. (2000) showed that increasing water content would decrease Indonesia sandstone's UCS and internal friction angle. The cohesion of the Mohr-Coulomb criterion even increased as the rock specimens became saturated (from 9.90 to 16.72 MPa). This was attributed to the inappropriateness of linear relationship of the sandstone specimen under wide range as well as high confining pressure by the researchers. Sachpazis (2004) found that saturation caused an increase in internal friction angle (up to 3.5 degrees) as well as a decrease in cohesion on the limestone from Northumberland England which was in different metamorphic grades. According to his study, saturation also caused an increase in Hoek and Brown $m_{i}$ material parameter as well as a decrease in UCS on the studied limestone. Li et al. (2005) observed that the jointed rock was more reactive to water than intact rock because of the high sensitivity of the residual friction angle to the presence of water. They also showed that after saturation the cohesive strength reduced from 14.1 to $10.3 \mathrm{MPa}$ and from 18.7 to $15.9 \mathrm{MPa}$ for the coarse grained and silty sandstones, respectively. Once the intact silty sandstone sample was saturated, the internal friction angle decreased from $48.6^{\circ}$ to $36.3^{\circ}$. For the coarse grained sandstone, no reduction occured in this parameter. Ergüler (2007) studied the effects of water content on different types of claybearing rock collected from various parts of Turkey. The results of triaxial tests showed that saturation caused a decrease both in cohesion and internal friction angle.

While comparing dry and saturated rock material, strength identification can be done directly according to UCS or deformability values. However, this identification cannot be so easy for triaxial compressive strength tests especially when the failure criteria parameters of Mohr-Coulomb changed inversely. For example, according to the studies of Lin and Hung (1982) and Ergüler (2007), where they noticed a decrease in both cohesion and internal friction angle, it is clear that intact rock strength also decreased. On the other hand, in the literature there are also studies in which cohesion and internal friction angle are changed inversely as in the studies by Kramadibrata et al. (2000) and Sachpazis (2004). This makes it difficult to make a definition according to rock material failure criterion parameters and so on triaxial compressive strength test results.

In this study; to overcome the difficulties encountered in definition of triaxial strength parameters as mentioned above, numerical modeling software, namely Phase2 (2002), was utilized as a tool in order to compare triaxial test results and the effect of rock material properties on rock mass behavior.

\section{GEOLOGY AND FIELD INVESTIGATIONS}

Tunçbilek coal basin comprises of two series Neogen sediments. The lower one is called as Tunçbilek series, in which the coal seam is located, and is in discordantly on an ophiolitic basement. The upper one is called as Domaniç series and this younger series lie on the Tunçbilek series with a slight discordance (Nebert, 1960; Basarır and Karpuz, 2004). In the Tunçbilek sub-basin, terrestrial and lacustrine sediments contain half-cemented conglomerates, claystones of fluviatile origin showing a fining-upward sequence, marls, siltstones, sandstones, lacustrine limestones, and lignite, located in the lower and upper parts of the sequence (Figure 1). The main lignite seam, from 7 to $15 \mathrm{~m}$ thick, includes claystone interlayers as well (Akkiraz et al., 2012).

Marl is the most common rock unit in open pits of Tunçbilek coal basin. The encountered marl formations in the field are gray and brown colored (Figure 2).

Tunçbilek open pit field observations were done according to the methods suggested by ISRM (2007) and Tunçbilek marl was defined as 'very blocky' and surface quality as 'fair' according to Geological

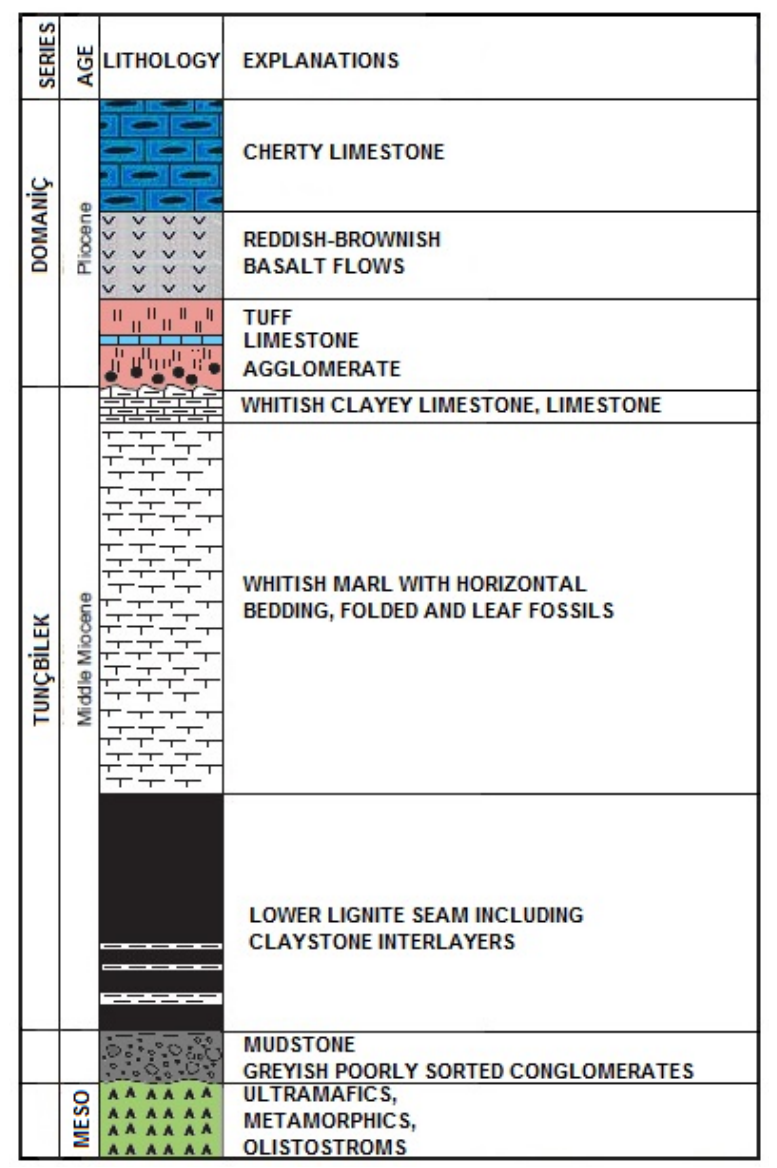

Fig. 1 Generalized stratigraphic column of the Tunçbilek sub-basin (Nebert, 1960; Akkiraz et al., 2012). 


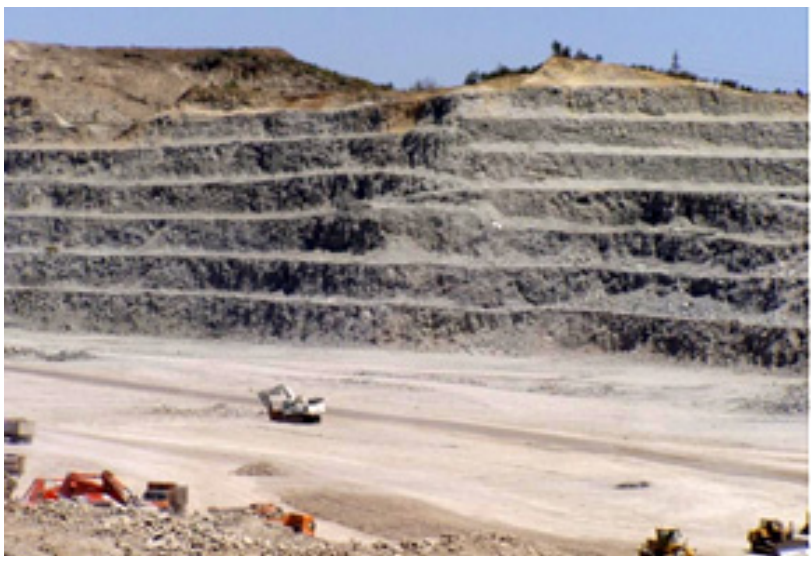

(a)

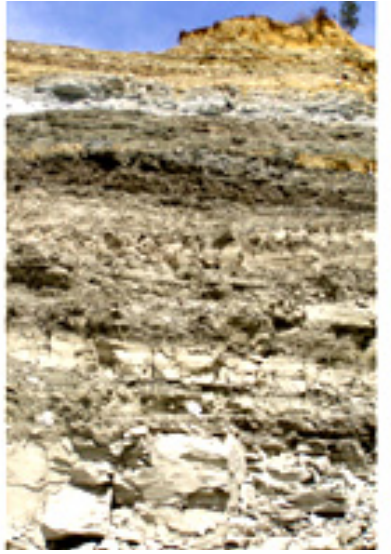

(b)

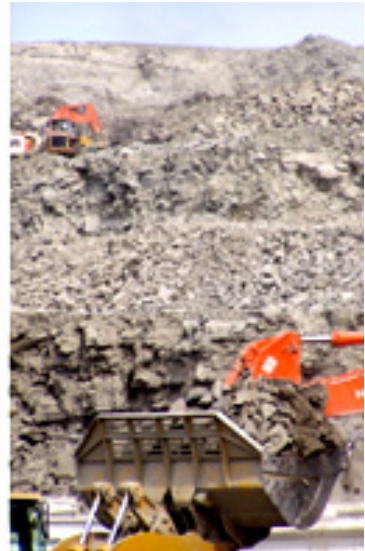

(c)

Fig. 2 A view from Tunçbilek open pits (a), Gray colored marl formation (b), Brown colored marl formation (c)

Strength Index (GSI) descriptions (Hoek, 1999). In detail; the roughness of discontinuities qualified as slightly rough and as smooth-undulating according to the observations on the discontinuity surfaces, the aperture and filling of discontinuities is $\quad<5 \mathrm{~mm}$ and soft filling is noticed, and the weathering degree is described as 'slightly weathered' according to the discoloration of the discontinuity surfaces and somewhat weaker externally than in its fresh condition. The GSI value of the marl rock mass was determined as 47 in light of the site definitions.

Besides these discontinuity investigations, mine climate measurements were carried out in TunçbilekÖmerler underground lignite mine. The temperature and Relative Humidity ( $\mathrm{RH}$ ) of the mine atmosphere were measured by employing thermo-hygrometer in September. It was determined that mine air has a humidity of $78 \%$ and average temperature of $17.5^{\circ} \mathrm{C}$ in main galleries, $82 \% \mathrm{RH}$ and $17.7^{\circ} \mathrm{C}$ in mechanized face. Mine air has an average of $80 \%$ $\pm 2 \mathrm{RH}$ and $17.6{ }^{\circ} \mathrm{C} \pm 0.1{ }^{\circ} \mathrm{C}$ temperature values. Also, water content of marl samples taken from the underground main gallery and from the mechanized face was determined as approximately $9 \%$ and $13 \%$, respectively. An average water content of marl was found to be $11 \%$.

\section{SAMPLING AND CONDITIONING}

Sample preparation stage involves test-specific cutting and sizing. On the other hand; it should also be supplied that samples to be tested have in situ properties, which is especially essential for the porous and water sensitive rocks. For this purpose, two different ways can be followed: The first way is to provide protection of in situ humidity of samples until test time, and the other way is the conditioning of samples whose natural moisture content has been changed.

For strength tests, block marl samples were taken from $860-880 \mathrm{~m}$ level of BY-H panel of open pit mines in Tunçbilek coal basin. NX core samples, whose ratio of length to diameter was 2-2.5, were taken from these blocks. In order to determine whether the color difference had an effect on the marl in the study, the samples were grouped by color as gray, brown and gray-brown sequence.

The optimum conditioning way of test samples before strength tests is to saturate them with water as the underground mining activities are generally maintained below the ground water level. For this purpose, a representative core sample taken from the each different block was immersed into the water. The disking behavior in some marl cores, especially in gray ones, was observed in less than half an hour (Figure 3). Such a water sensitivity of marls in Tunçbilek region has been mentioned in several studies (Eskikaya et al., 1991; Esmek et al., 1993).

Instead of direct treatment with water, the conditioning studies on Tunçbilek marl samples were
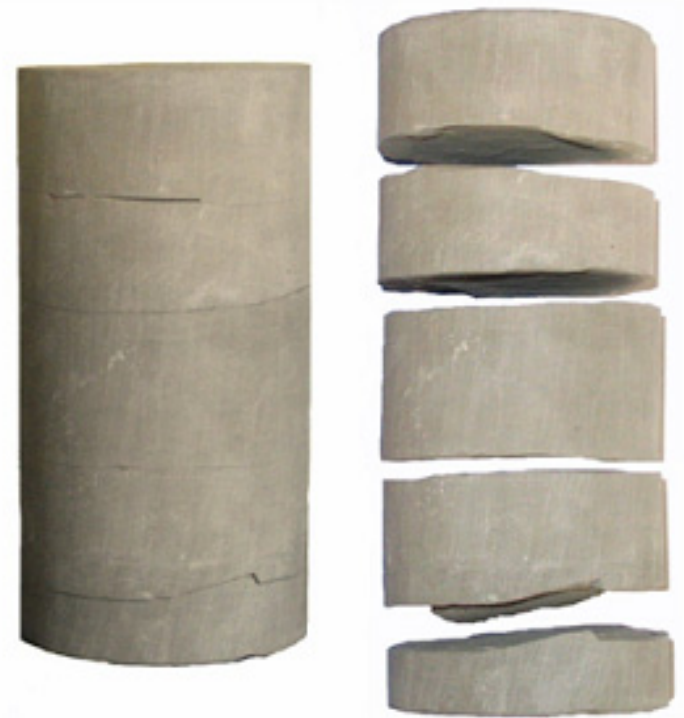

Fig. 3 An example of disking on gray marl samples with water effect. 


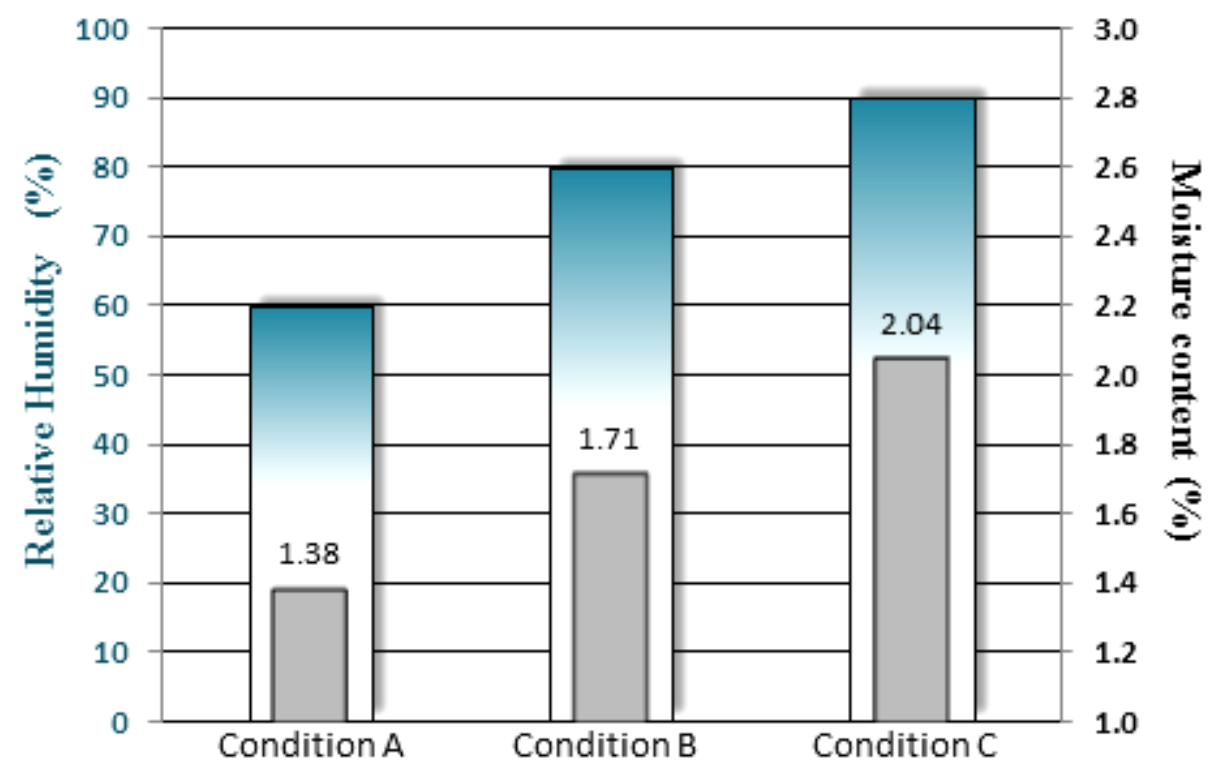

Fig. 4 Variation in moisture content of marl conditioned at different RH and constant temperature of $17.6^{\circ} \mathrm{C}$ in climate cabin.

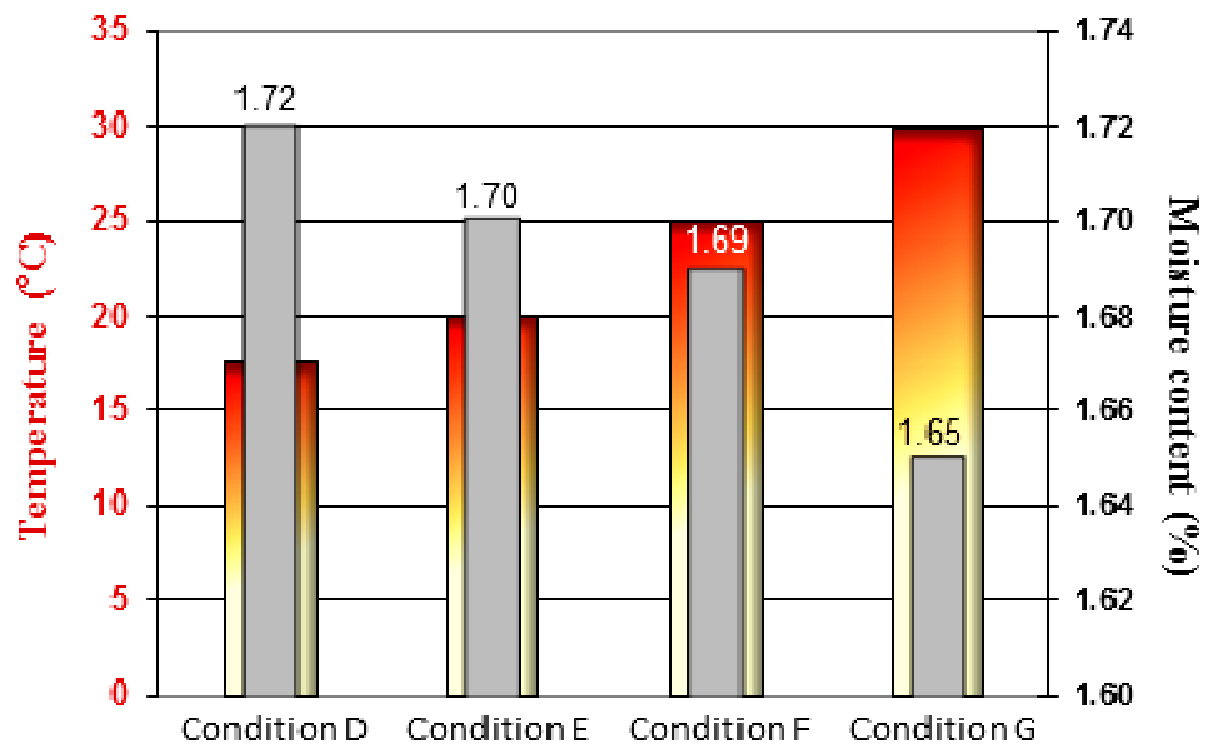

Fig. 5 Variation in moisture content of marl conditioned at different temperatures and constant $\mathrm{RH}$ of $80 \%$ in climate cabin.

carried out in a climate cabin. Pure water was used in the climate cabin. Ten oven dried marl samples were placed in the climate cabin. The temperature of the climate cabin was constantly kept at $17.6{ }^{\circ} \mathrm{C}$, representing Tunçbilek coal mine atmosphere, while $\mathrm{RH}$ values were changed. On contrary, the RH was constantly kept at $80 \%$ while temperature values were changed. For all different conditions; the samples were kept in the climate cabin for 10-15 days until they reached the equilibrium mass, and daily mass change in rock samples was recorded. Even though the samples were in equilibrium mass, they also kept 2-3 more days in order to be sure whether the equilibrium mass is reached or not. It was preferred to keep the studied rock samples maximum 15 days in climate cabinet during experimental studies since there is no mass change was observed after 15 days of keeping time.

The moisture adsorption by mass of conditioned marl samples was given in Figure 4 and 5 . It can be realized from Figure 4 the moisture content by mass of a marl sample is increased by increasing $\mathrm{RH}$ at the constant temperature. The moisture content by mass of marl samples decreased by increasing temperature at the constant RH value (Figure 5). As a result of these studies, the optimum conditioning for Tunçbilek marl was found to be $17.6{ }^{\circ} \mathrm{C}$ temperature and $90 \%$ $\mathrm{RH}$ (Condition C) by taking account of working 


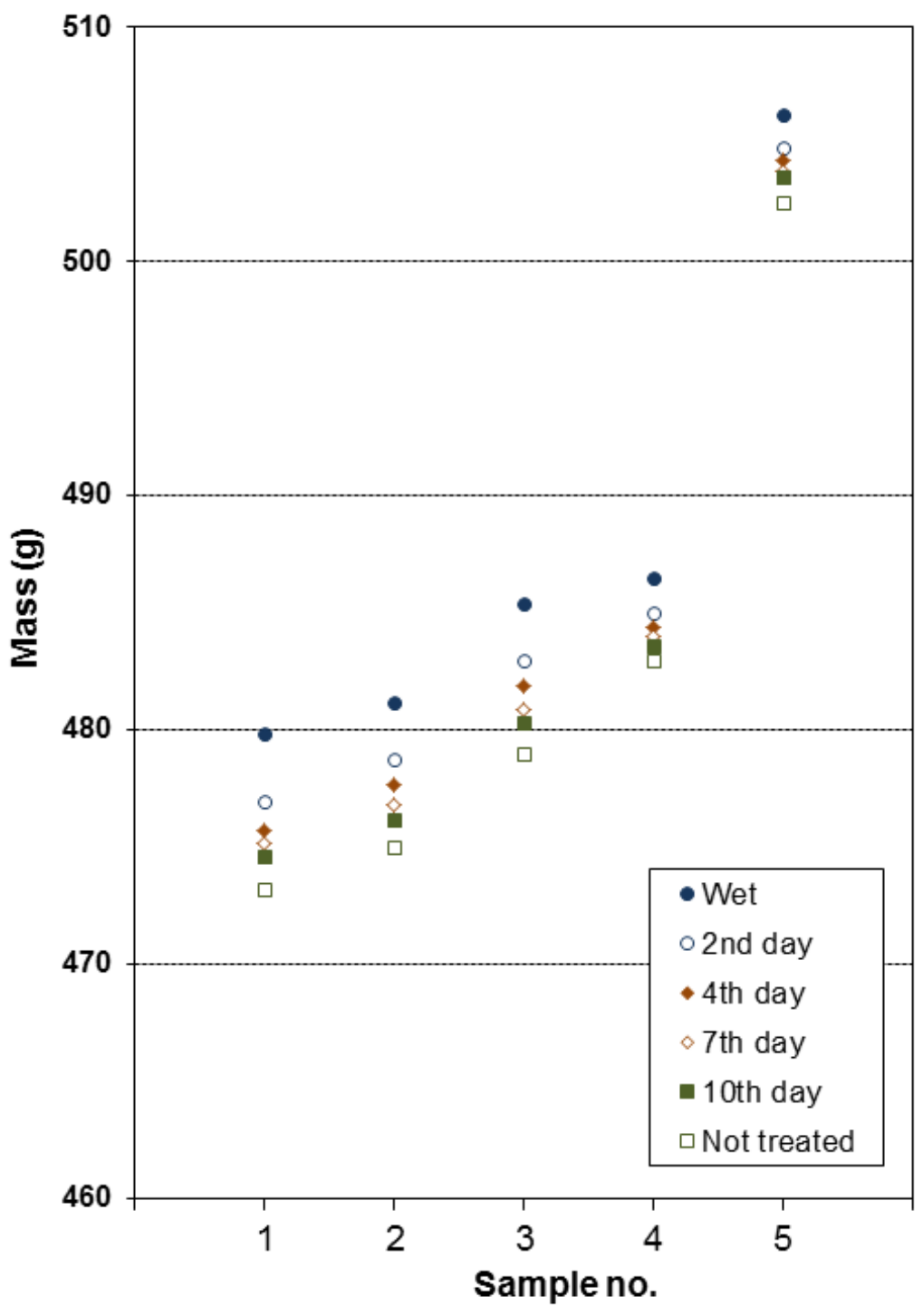

Fig. 6 Variation in moisture content of marl samples treated by immersion.

efficiency of the climate cabin and underground mine climate. In this way, the samples could be moisturised to the rate of $2 \%$.

In order to see how wet samples could keep their water content in different climate conditions, a simple test was conducted. Firstly, five marl samples were put into the climate cabin which was adjusted to $22{ }^{\circ} \mathrm{C}$ and $80 \%$ RH. When they reached the constant masses, their masses were recorded as 'not treated'. Then samples were wetted by immersion. They weren't kept in water long in order to avoid disking. When their 'wet' masses were recorded, they were put into the cabin which has the previous setting. Their masses were measured periodically until they reached to the constant masses. The obtained results were given graphically in Figure 6. As a result, the marl is not keeping its present moisture content in different climate and it adapts to new conditions.

In order to assay effect of changes in climate on strength, four different condition alternatives were selected as a preparation for strength tests. One group from test samples was conditioned oven dried, while others at $17.6{ }^{\circ} \mathrm{C}$ temperature and $60 \% \mathrm{RH}, 80 \% \mathrm{RH}$ and $90 \% \mathrm{RH}$ until they reached to the constant mass. On the other hand, tests were conducted separately on two main groups of gray and brown marl samples. Totally, tests were conducted on 8 different sample groups according to conditioning type and color difference.

\section{TRIAXIAL COMPRESSION TESTS AND INTACT ROCK FAILURE CRITERIA PARAMETERS}

Triaxial compression tests were performed on oven dried marl samples and conditioned in $60 \% \mathrm{RH}$, $80 \% \mathrm{RH}$ and $90 \% \mathrm{RH}$ at $17.6{ }^{\circ} \mathrm{C}$. Tests were carried out according to the methods suggested by ISRM (1983) and by Hoek-Brown in 1997. The tests were 
Table 1 Triaxial compressive strength test results (Beyhan, 2008).

\begin{tabular}{|c|c|c|c|c|c|c|c|c|c|c|c|c|}
\hline \multirow[b]{2}{*}{ Color } & \multicolumn{3}{|l|}{ Dried } & \multicolumn{3}{|c|}{$60 \%$ RH- $17.6^{\circ} \mathrm{C}$} & \multicolumn{3}{|c|}{$80 \% \mathrm{RH}-17.6^{\circ} \mathrm{C}$} & \multicolumn{3}{|c|}{$90 \% \mathrm{RH}-17.6^{\circ} \mathrm{C}$} \\
\hline & $\begin{array}{l}\text { Sample } \\
\text { No. }\end{array}$ & $\begin{array}{l}\sigma_{1} \\
(\mathrm{MPa})\end{array}$ & $\begin{array}{l}\sigma_{3} \\
(\mathrm{MPa})\end{array}$ & $\begin{array}{l}\text { Sample } \\
\text { No. }\end{array}$ & $\begin{array}{l}\sigma_{1} \\
(\mathrm{MPa})\end{array}$ & $\begin{array}{l}\sigma_{3} \\
(\mathrm{MPa})\end{array}$ & $\begin{array}{l}\text { Sample } \\
\text { No. }\end{array}$ & $\begin{array}{l}\sigma_{1} \\
(\mathrm{MPa})\end{array}$ & $\begin{array}{l}\sigma_{3} \\
(\mathrm{MPa})\end{array}$ & $\begin{array}{l}\text { Sample } \\
\text { No. }\end{array}$ & $\begin{array}{l}\sigma_{1} \\
(\mathrm{MPa})\end{array}$ & $\begin{array}{l}\sigma_{3} \\
(\mathrm{MPa})\end{array}$ \\
\hline \multirow{6}{*}{ Gray } & 1 & 55.9 & 1 & 12 & 39.4 & 1 & 23 & 41.3 & 1 & 34 & 38.6 & 1 \\
\hline & 2 & 45.1 & 1 & 13 & 46.2 & 2 & 24 & 42.8 & 2 & 35 & 43.5 & 2 \\
\hline & 3 & 54.1 & 2 & 14 & 46.8 & 3 & 25 & 44.4 & 3 & 36 & 50.5 & 3 \\
\hline & 4 & 61.2 & 3 & 15 & 52.8 & 4 & 26 & 49.9 & 4 & 37 & 34.7 & 4 \\
\hline & 5 & 61.1 & 4 & 16 & 53.0 & 5 & 27 & 55.0 & 5 & 38 & 52.8 & 4 \\
\hline & 6 & 60.3 & 5 & & & & & & & 39 & 56.5 & 5 \\
\hline \multirow{6}{*}{ Brown } & 7 & 56.3 & 1 & 17 & 56.9 & 1 & 28 & 42.9 & 1 & 40 & 50.4 & 1 \\
\hline & 8 & 74.3 & 3 & 18 & 59.2 & 3 & 29 & 47.0 & 3 & 41 & 47.7 & 3 \\
\hline & 9 & 76.6 & 5 & 19 & 63.5 & 5 & 30 & 71.0 & 5 & 42 & 41.1 & 5 \\
\hline & 10 & 67.9 & 7 & 20 & 103.4 & 7 & 31 & 56.9 & 5 & 43 & 67.4 & 7 \\
\hline & 11 & 95.2 & 9 & 21 & 64.3 & 7 & 32 & 67.4 & 7 & 44 & 82.6 & 9 \\
\hline & & & & 22 & 82.4 & 9 & 33 & 72.2 & 9 & & & \\
\hline
\end{tabular}

Table 2 Parameters of failure criteria for intact rock.

\begin{tabular}{|c|c|c|c|c|c|}
\hline \multirow[b]{2}{*}{ Conditioning type } & \multirow[b]{2}{*}{ Color } & \multicolumn{2}{|c|}{ Mohr-Coulomb } & \multicolumn{2}{|c|}{ Hoek-Brown } \\
\hline & & $\begin{array}{c}\mathrm{c} \\
(\mathrm{MPa})\end{array}$ & $\begin{array}{l}\phi \\
\left({ }^{\circ}\right)\end{array}$ & $\begin{array}{l}\sigma_{\mathrm{ci}} \\
(\mathrm{MPa}\end{array}$ & $m_{i}$ \\
\hline \multirow{3}{*}{ Dried } & Gray & 12.36 & 32.86 & 48.31 & 4.26 \\
\hline & Brown & 12.57 & 37.76 & 55.35 & 6.36 \\
\hline & Gray \& brown & 9.85 & 41.34 & 47.15 & 8.65 \\
\hline \multirow{3}{*}{$60 \%$ RH- $17.6^{\circ} \mathrm{C}$} & Gray & 8.57 & 36.76 & 36.85 & 5.85 \\
\hline & Brown & 10.44 & 40.38 & 48.87 & 7.95 \\
\hline & Gray \& brown & 6.87 & 45.73 & 36.01 & 13.00 \\
\hline \multirow{3}{*}{$80 \%$ RH $-17.6^{\circ} \mathrm{C}$} & Gray & 8.41 & 36.61 & 36.00 & 5.77 \\
\hline & Brown & 7.83 & 41.38 & 37.53 & 8.68 \\
\hline & Gray \& brown & 6.91 & 42.69 & 34.07 & 9.77 \\
\hline \multirow{3}{*}{$90 \% \mathrm{RH}-17.6^{\circ} \mathrm{C}$} & Gray & 8.79 & 34.67 & 35.92 & 4.93 \\
\hline & Brown & 7.98 & 40.30 & 37.31 & 7.89 \\
\hline & Gray \& brown & 7.09 & 41.23 & 33.84 & 8.56 \\
\hline
\end{tabular}

repeated on 5 samples belonging to the same group rock material by applying different constant horizontal pressures. Lateral pressure was applied in such a way that would not exceed half of the uniaxial compressive strength value of the rock material. During the application of individual test method, the axial load was supplied by the hydraulic press and NX Hoek cell was used for the confining pressure. The effective principal stresses $\left(\sigma_{1}, \sigma_{3}\right)$ at failure were recorded and are given in Table 1 .

Mohr-Coulomb and Hoek-Brown failure criteria parameters for intact rock were calculated in RocLab software (2007) by using effective principal stresses found in triaxial compression tests at failure, and the results are as given in Table 2. Both gray and brown test results were taken together for gray-brown marl in RocLab software as to be representative for the whole area marl.

As seen in Table 2; when the parameters of failure criteria for intact rock in dried conditions was compared with those of the other conditions $(60,80$, $90 \% \mathrm{RH}$ and $17.6^{\circ} \mathrm{C}$ ), the cohesion value of gray and brown marl rock material decreased while the internal friction angle increased. Besides, in Hoek-Brown parameters, while they caused a decrease in UCS, they led to an increase in $m_{i}$ value. Especially the inverse relationship between Mohr-Coulomb failure criterion parameters causes difficulties for the definition of intact rock strength. In this study, numerical modeling was used to determine the intact rock strength properties based on triaxial compressive strength.

\section{NUMERICAL MODEL ANALYSES}

Phase2 software (2002) was employed for numerical modeling analyses to investigate rock mass behaviour. Before constructing any underground opening in Phase2, previous projects (Eskikaya et al., 1991; Esmek et al., 1993), designed for deep coal mines at the studied site, have been considered for the numerical models. In these projects, four different 


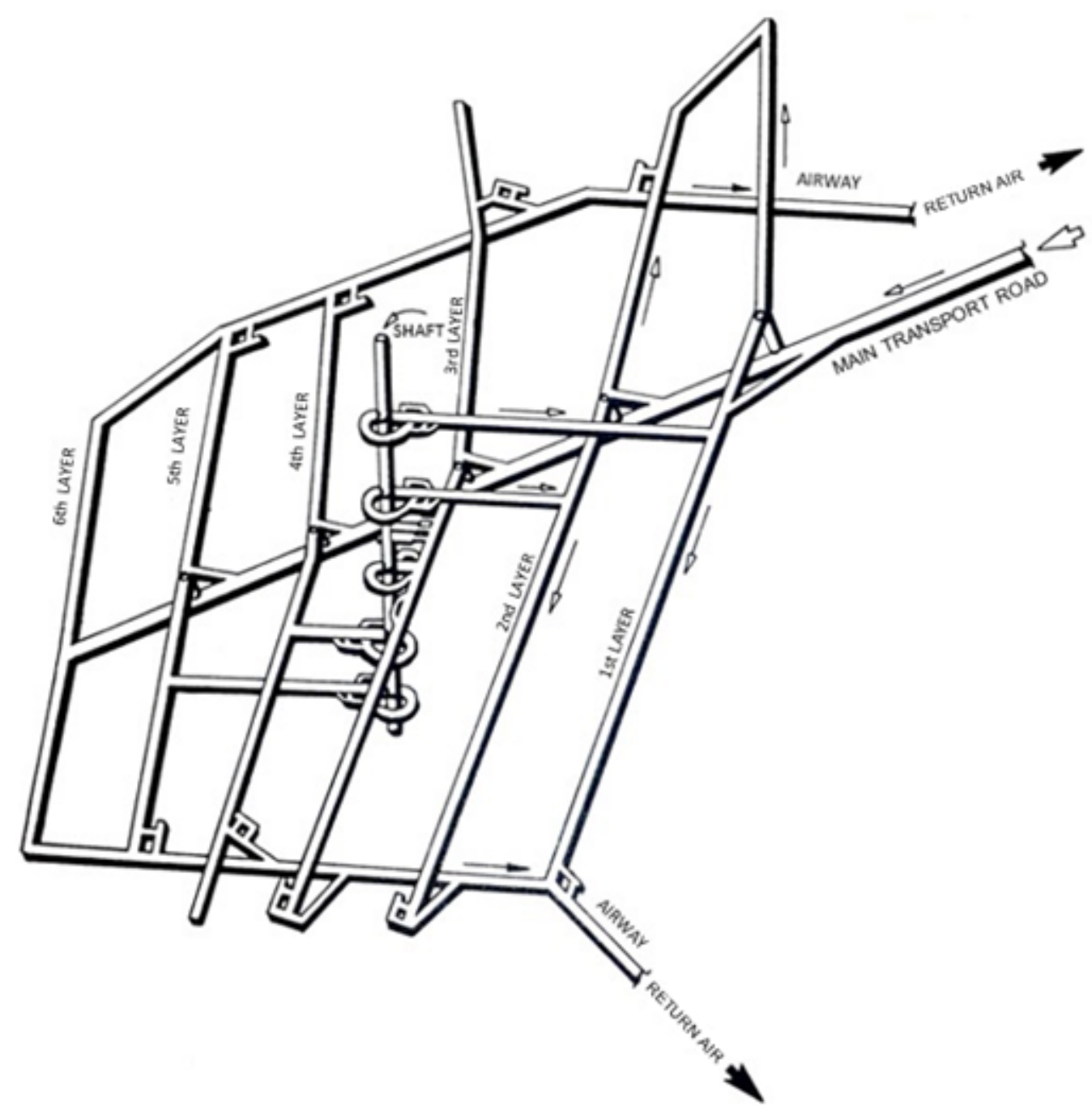

Fig. 7 N-S section of mine according to suggested method by Eskikaya et al. (1991).

alternatives for reaching deep coal seam were evaluated by Eskikaya et al. and the most proper, economical and practical method was suggested as shown in Figure 7.

It has been estimated to be driven B-14 type galleries over $35 \mathrm{~km}$ in length according to the proposed project for deep coal seams in Tunçbilek. Therefore, B-14 type gallery opening was the most common mining opening section in the projects in question, and it has currently been used in the mine. By making use of idealized static model geometry (Birön and Arığlu, 1985), a B-14 gallery section was modeled without ground support in the present numerical models. Considering the idealized static model, gallery height and length was chosen as $3750 \mathrm{~mm}$ and $5000 \mathrm{~mm}$ (Figure 8), respectively.

The surrounding rock mass is considered as marl in the numerical models since the galleries have been planned to be driven in the formation just above the coal seam as seen in generalized stratigraphic column in Figure 1.

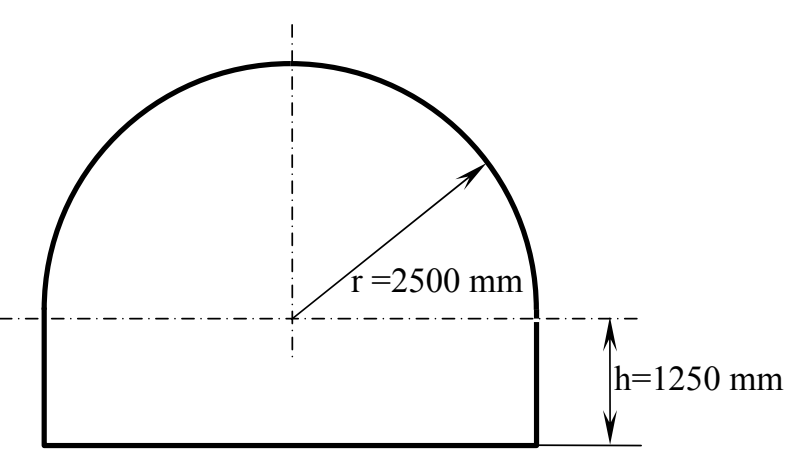

Fig. 8 Idealized statistical model of B-14 galleries.

In situ stress components were calculated for $600 \mathrm{~m}$ depth by taking into account the mining projects mentioned before. In numerical analyses; 24 elasto-plastic numerical models were solved by taking into account the variation of some parameters such as field stress, disturbance factor, conditioning method 

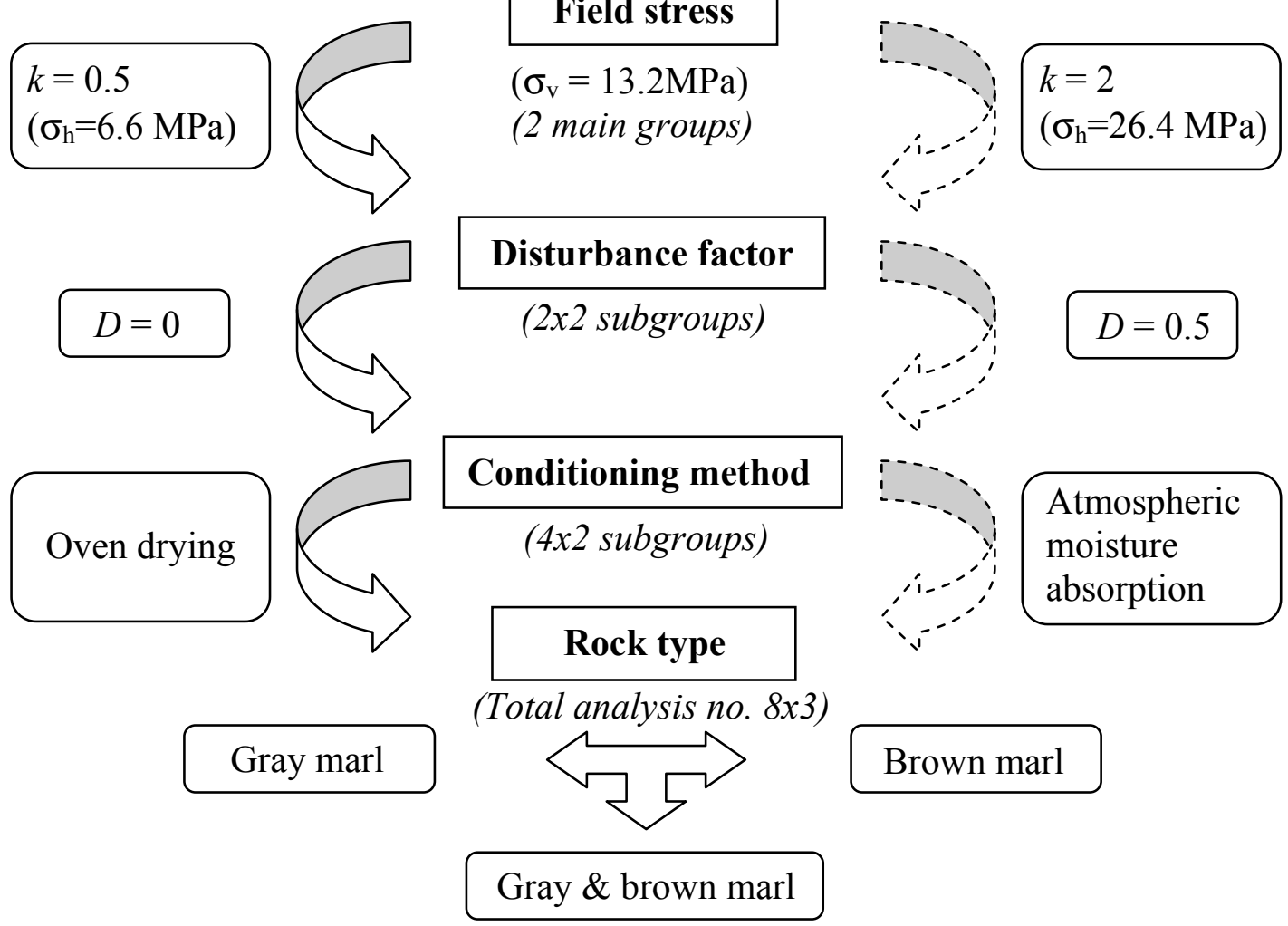

\section{Brown marl}

Fig. 9 Numerical model analyses schedule.

Table 3 The $m_{b}, s$ and $a$ parameters of rock mass.

\begin{tabular}{|c|c|c|c|c|c|c|c|}
\hline \multirow{3}{*}{ Conditioning } & \multirow{3}{*}{ Color } & \multicolumn{6}{|c|}{$\begin{array}{l}\text { Geological strength index } \\
G S I=47\end{array}$} \\
\hline & & \multicolumn{6}{|c|}{ Disturbance factor } \\
\hline & & $m_{b}$ & $s$ & $a$ & $m_{b}$ & $s$ & $a$ \\
\hline \multirow{3}{*}{ Dried } & Gray & 0.642 & 0.0028 & 0.507 & 0.341 & 0.0009 & 0.507 \\
\hline & Brown & 0.958 & 0.0028 & 0.507 & 0.510 & 0.0009 & 0.507 \\
\hline & Gray \& brown & 1.303 & 0.0028 & 0.507 & 0.693 & 0.0009 & 0.507 \\
\hline \multirow{3}{*}{$90 \%$ RH- $17.6^{\circ} \mathrm{C}$} & Gray & 0.743 & 0.0028 & 0.507 & 0.395 & 0.0009 & 0.507 \\
\hline & Brown & 1.189 & 0.0028 & 0.507 & 0.632 & 0.0009 & 0.507 \\
\hline & Gray \& brown & 1.289 & 0.0028 & 0.507 & 0.686 & 0.0009 & 0.507 \\
\hline
\end{tabular}

and rock type. For the field stress, two main groups were constructed by using the ratio of average horizontal stresses to vertical stress $(k)$ as 0.5 and 2 (Figure 9). Blast Damage Factor $(D)$ formerly known as "Disturbance factor" to account for stress relaxation and blast damage was taken as 0 and 0.5 for the excavation technique causing no disturbance and medium level of damage, respectively. In this way, 2x2 subgroups of numerical models have been revealed in order to research the effect of disturbance factor. For each disturbance factor $(D=0$ and $D=0.5)$, 2 subgroups of numerical models which is designed to investigate the conditioning method have been generated by using data based on marl's strength properties in oven dried and conditioned at $17.6{ }^{\circ} \mathrm{C}$ and $90 \% \mathrm{RH}$. Besides, the fact that marl in Garp Lignite Enterprise (GLE) lignite basin is in three groups according to its color namely: gray, brown and gray-brown sequence required three separate modeling analyses for each subgroup. Figure 9 shows the groups and subgroups for numerical models designed for combination of mentioned parameters.

The rock mass $m_{b}, s$ and $a$ parameters shown in Table 3 were determined by employing the RocLab software (2007). 


\section{Dried}

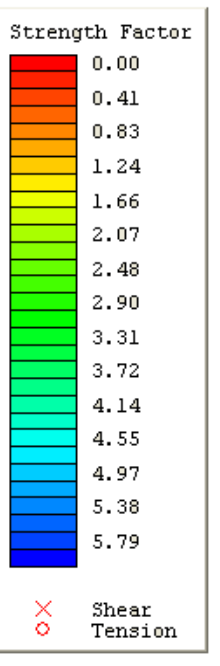

\section{a) Gray}

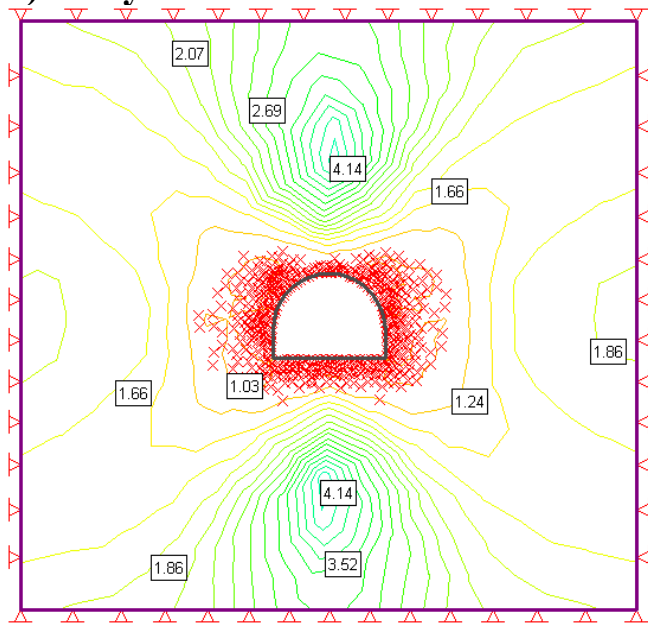

\section{b) Brown}

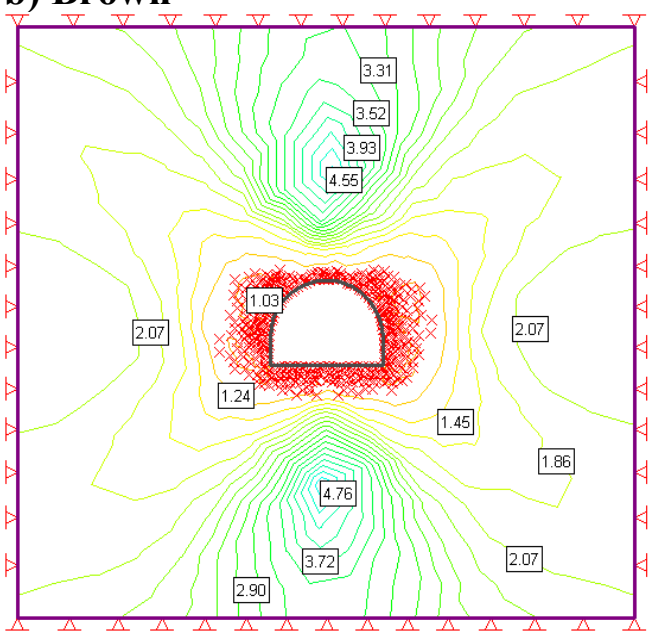

c) Gray \& brown

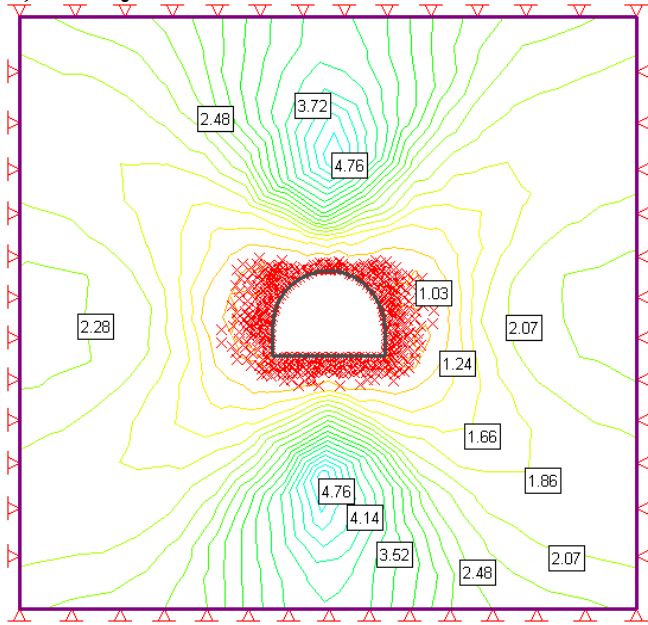

\section{Humid}

d) Gray

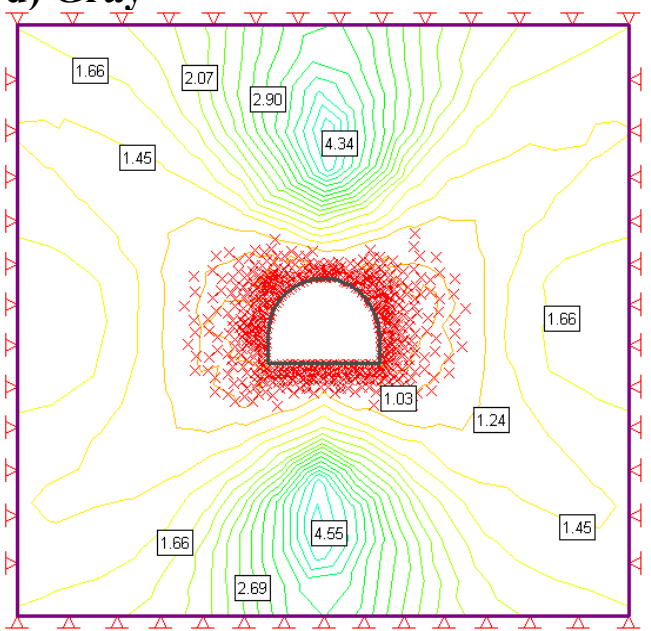

e) Brown

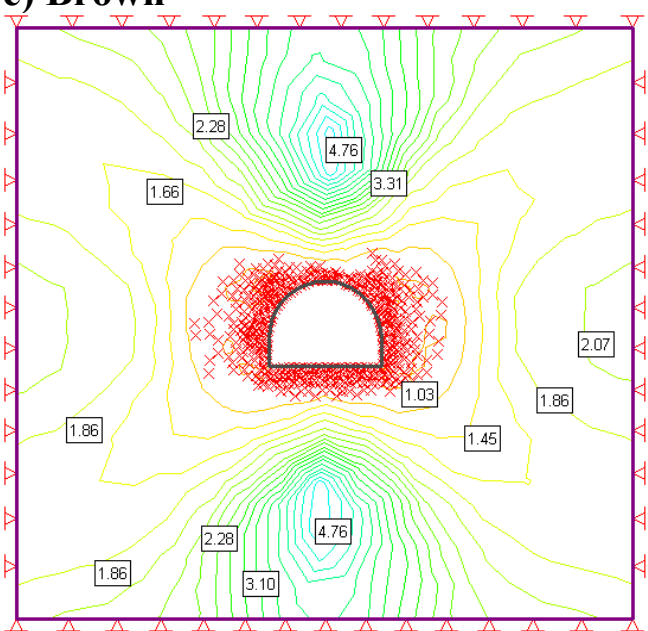

\section{f) Gray \& brown}

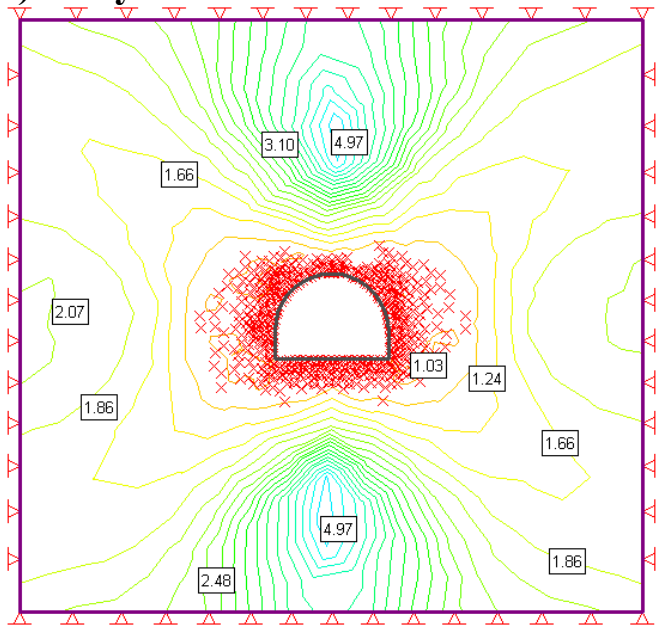

Fig. 10 Strength factor values and yielded elements around the opening according to the numerical model analyses $(k=0.5 ; D=0)$ (Beyhan, 2008).

\section{RESULTS AND DISCUSSIONS}

According to the results of 24 separate numerical modeling analyses, the changes in strength factor of the opening and failure points were given in Figures 10-13. Accordingly, failure points around the opening increased in case of $k=2$ when compared to $k=0.5$, i.e. Figure $10 \mathrm{a}$ and Figure $12 \mathrm{a}$, Figure $10 \mathrm{~b}$ and Figure $12 \mathrm{~b}$ and so on. The fact that the rock mass was disturbed also led to an increase in disturbed points. When the marl was humid, the disturbed points 
Dried

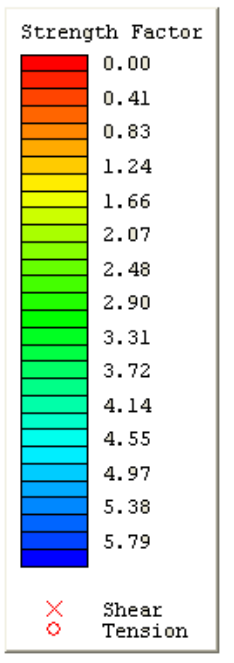

a) Gray

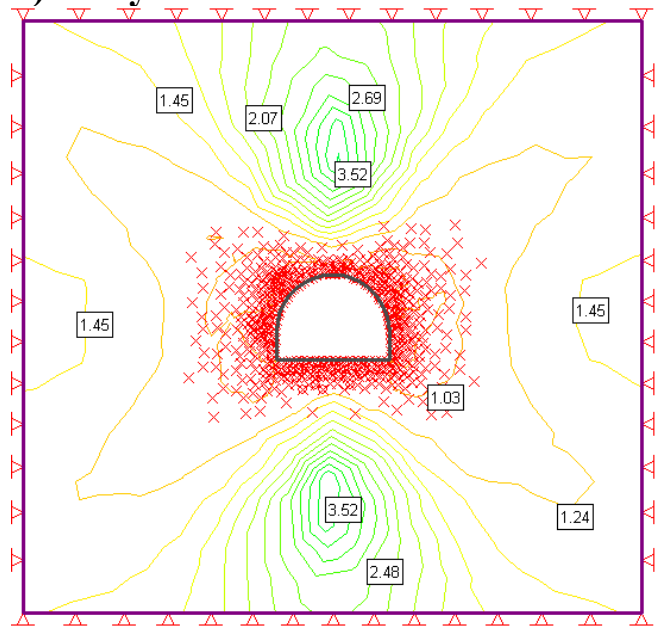

b) Brown

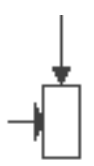

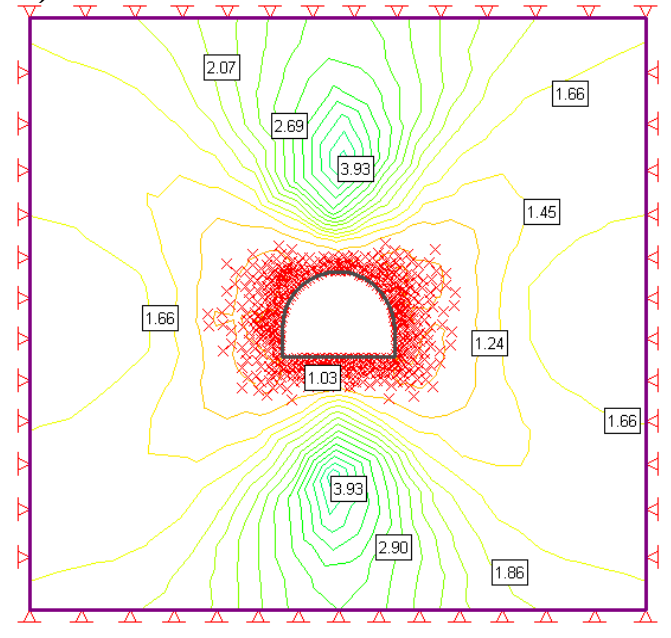

c) Gray \& brown

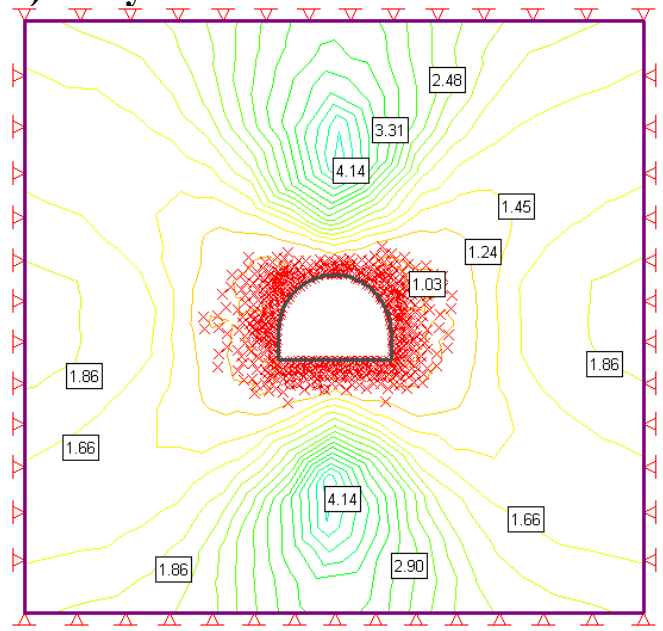

Humid

d) Gray

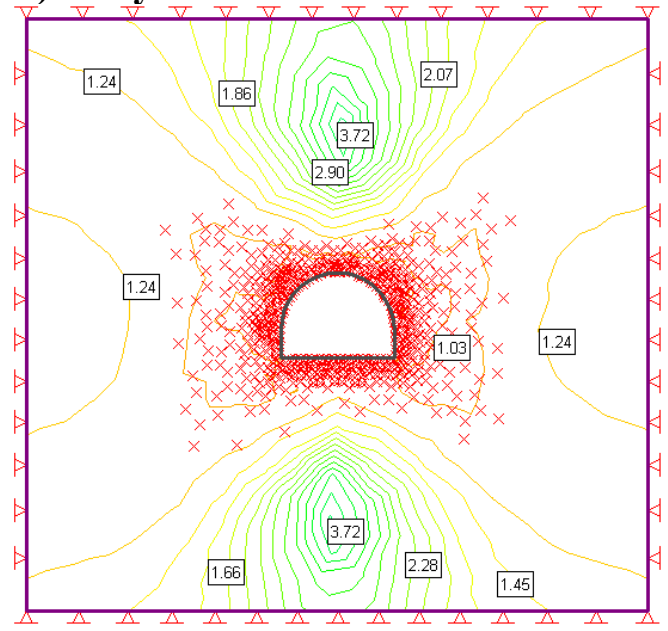

e) Brown

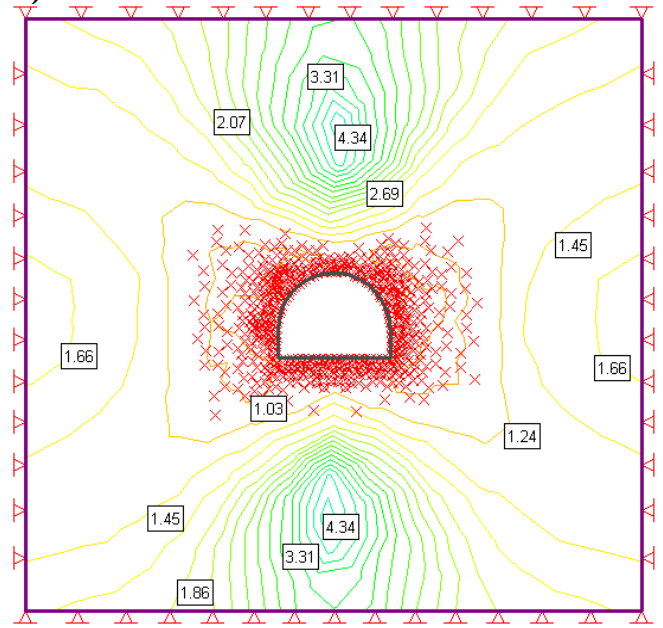

\section{f) Gray \& brown}

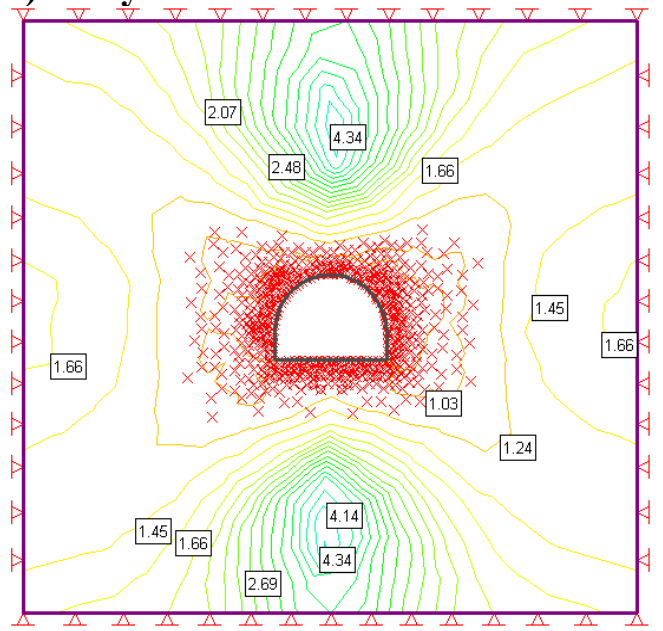

Fig. 11 Strength factor values and yielded elements around the opening according to the numerical model analyses $(k=0.5 ; D=0.5)$ (Beyhan, 2008).

around the opening also increased significantly. In other words, humidity had a negative effect on the behavior of marl rock mass.

In terms of color property of marl, when the rock mass around the opening was gray marl, more disturbances occurred around the opening when compared to brown marl (e.g. Figure 10a and 10b ). When the rock mass around the opening was graybrown sequence marl, more disturbances occurred around the opening compared to brown marl and fewer disturbances occurred compared to brown marl. 
$\underline{\text { Dried }}$

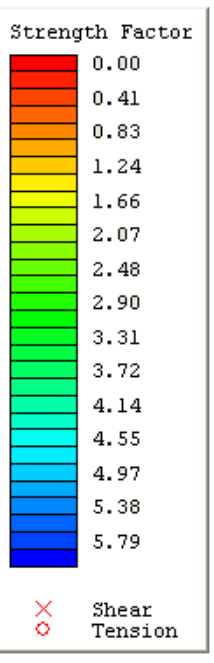

\section{a) Gray}

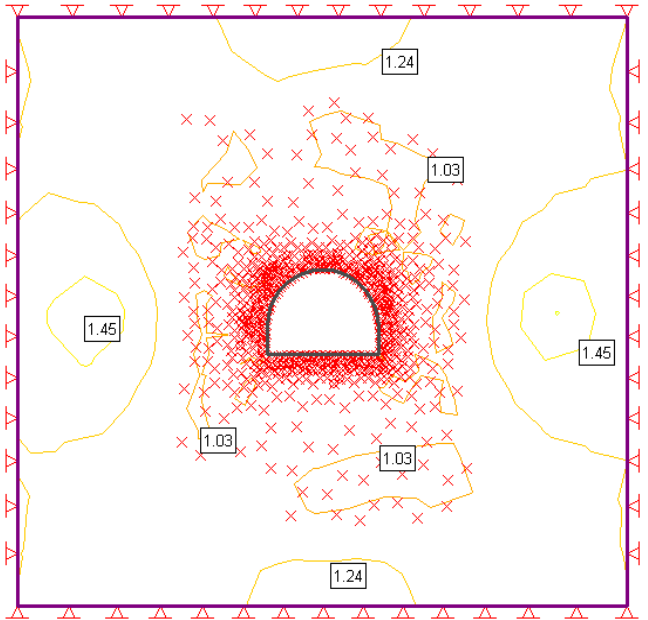

b) Brown

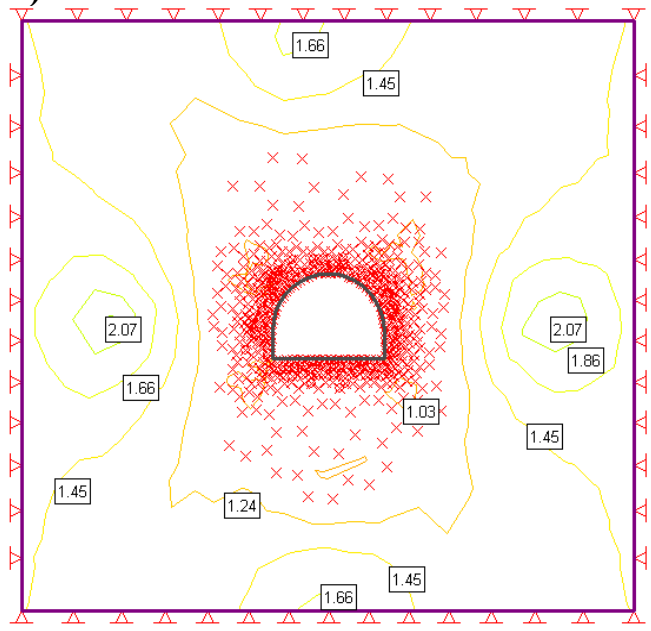

c) Gray \& brown

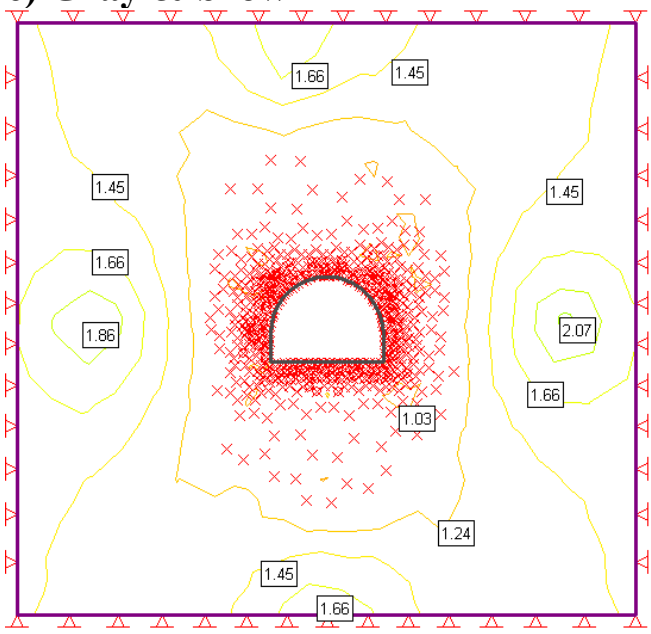

Humid

d) Gray

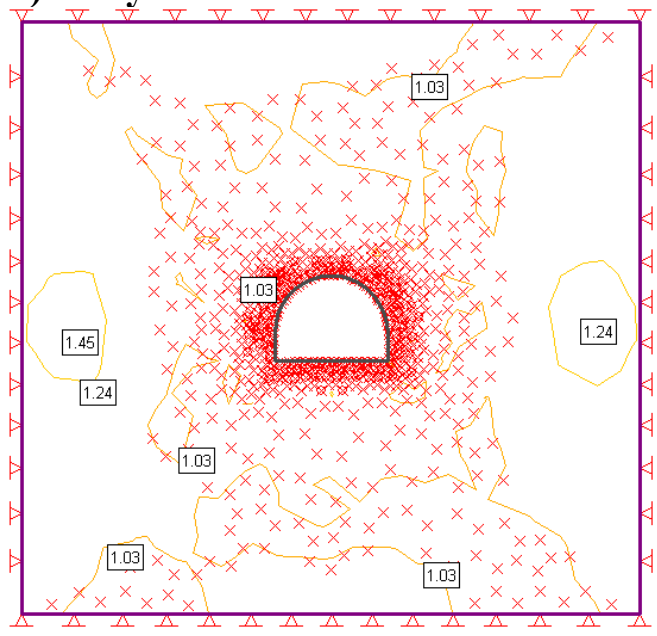

e) Brown

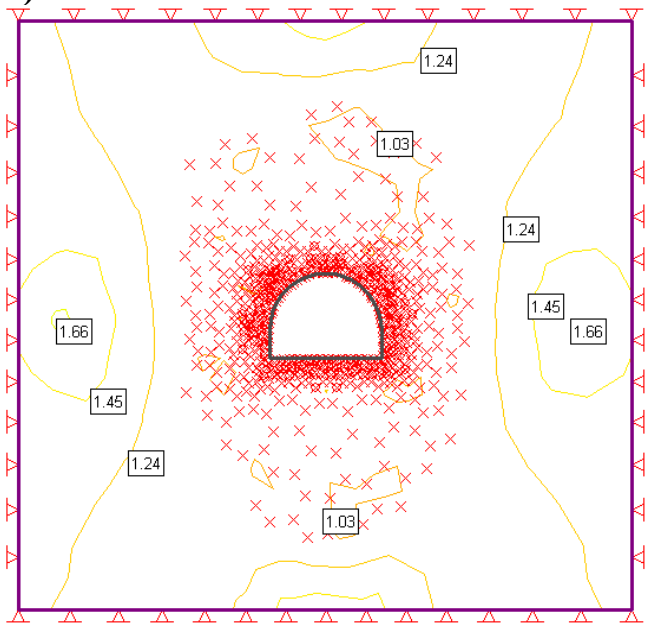

f) Gray \& brown

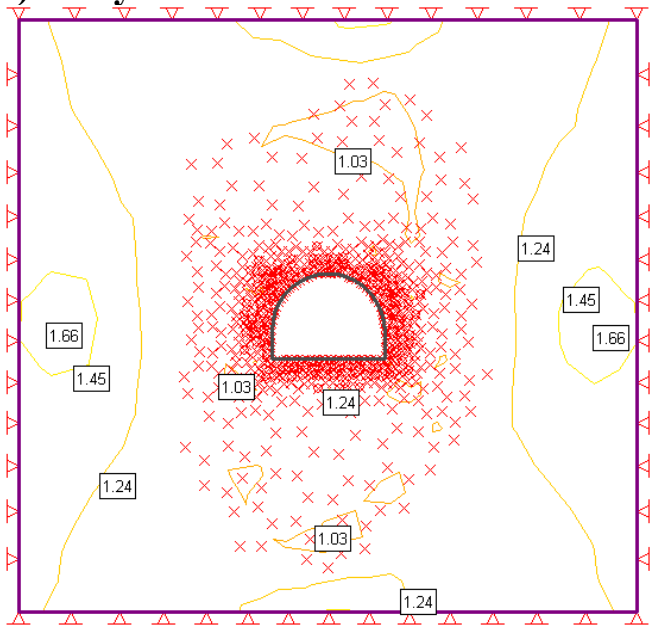

Fig. 12 Strength factor values and yielded elements around the opening according to the numerical model analyses $(k=2 ; D=0)$ (Beyhan, 2008).

As a result of numerical modeling analyses, maximum and minimum effective stress dispersion around the gallery opening together with horizontal, vertical and total displacements were obtained as shown in the graphs in Figures 14 and 15.
According to Figure 14, it can be seen that maximum and minimum effective stress values are relatively high when $k=2$. No significant differences are observed in stress values depending on disturbance, color and moisture. However, maximum 
Dried

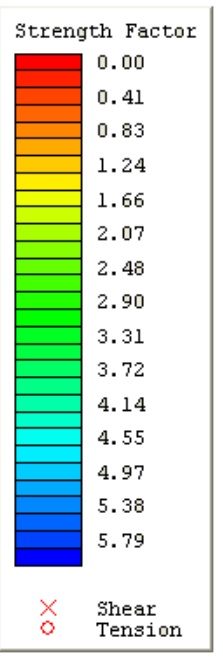

\section{a) Gray}

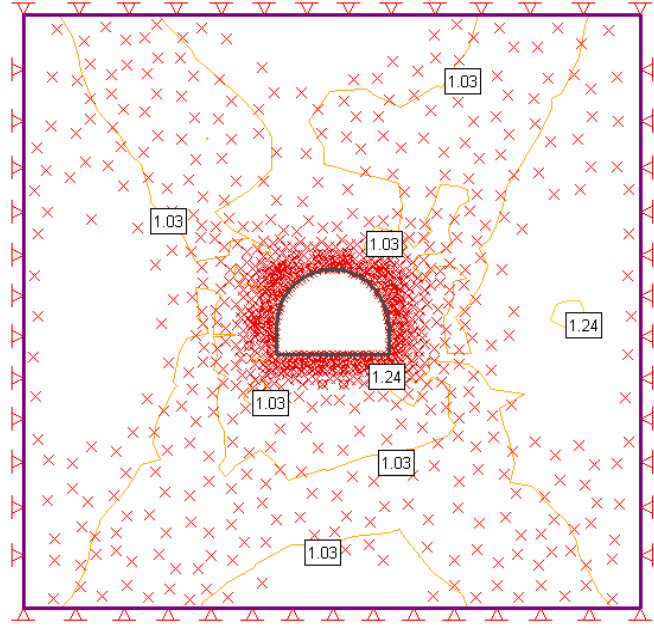

b) Brown

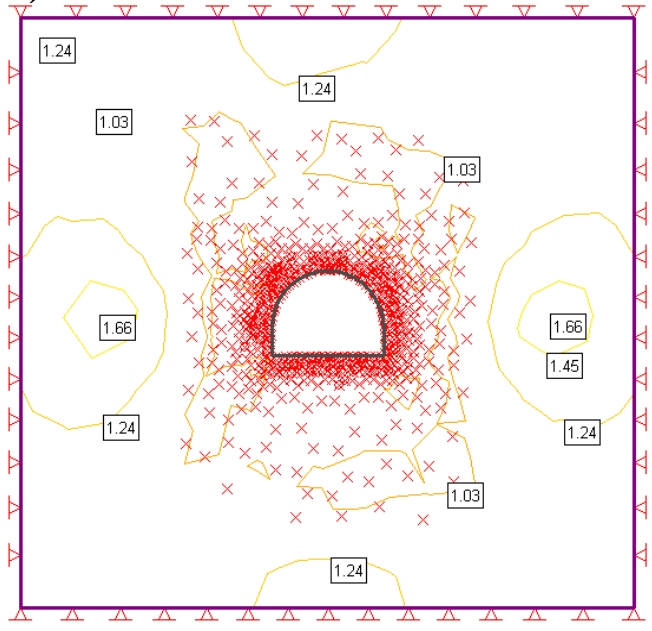

c) Gray \& brown

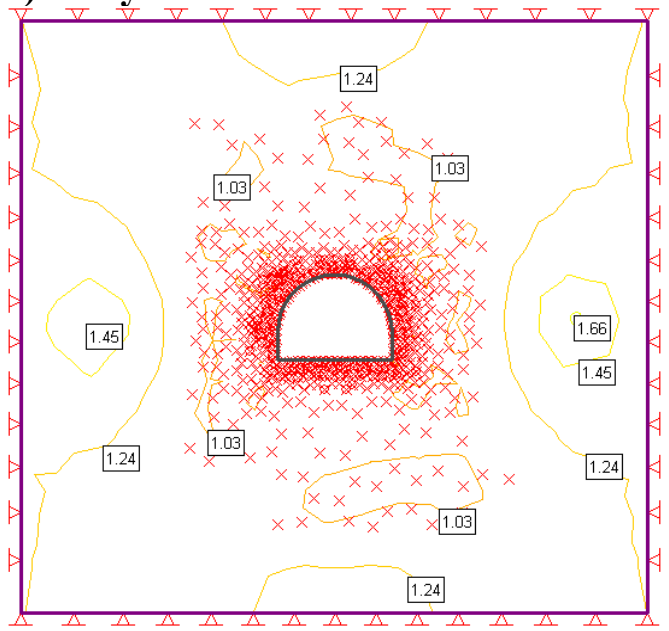

Humid

d) Gray

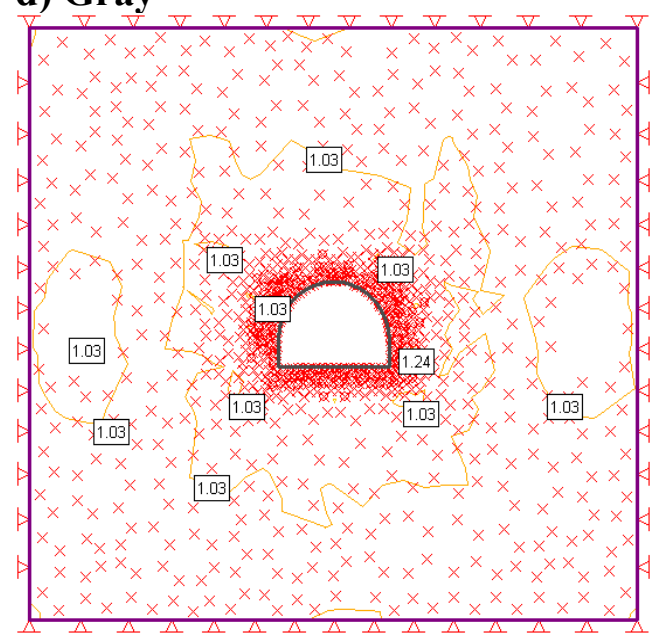

e) Brown

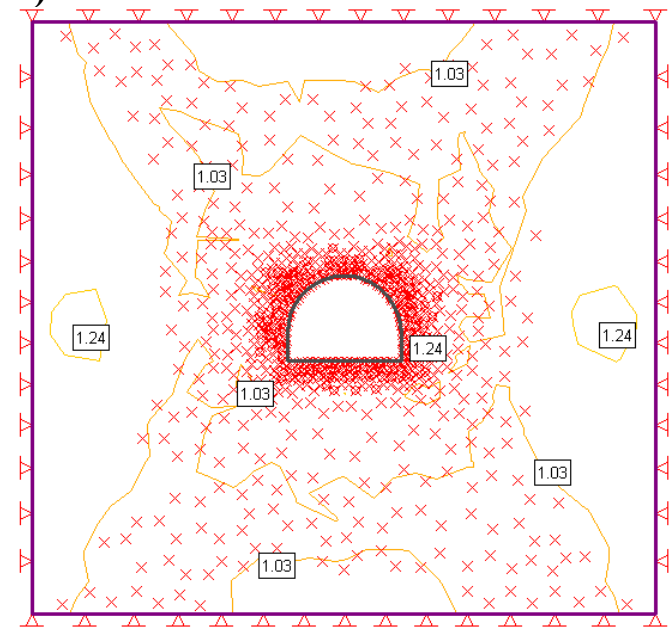

f) Gray \& brown

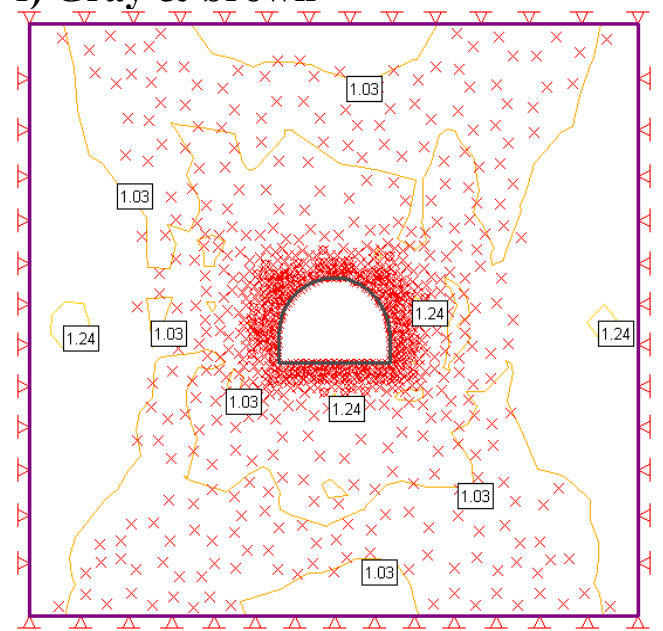

Fig. 13 Strength factor values and yielded elements around the opening according to the numerical model analyses $(k=2 ; D=0.5)$ (Beyhan, 2008).

and minimum effective stress values observed higher when rock material is dry and without disturbance. Therefore, moisture and disturbance can be said to decrease the values of effective stress components that rock mass might encounter. No outstanding effect is observed on stress components when marl rock mass is gray, brown or gray-brown. 


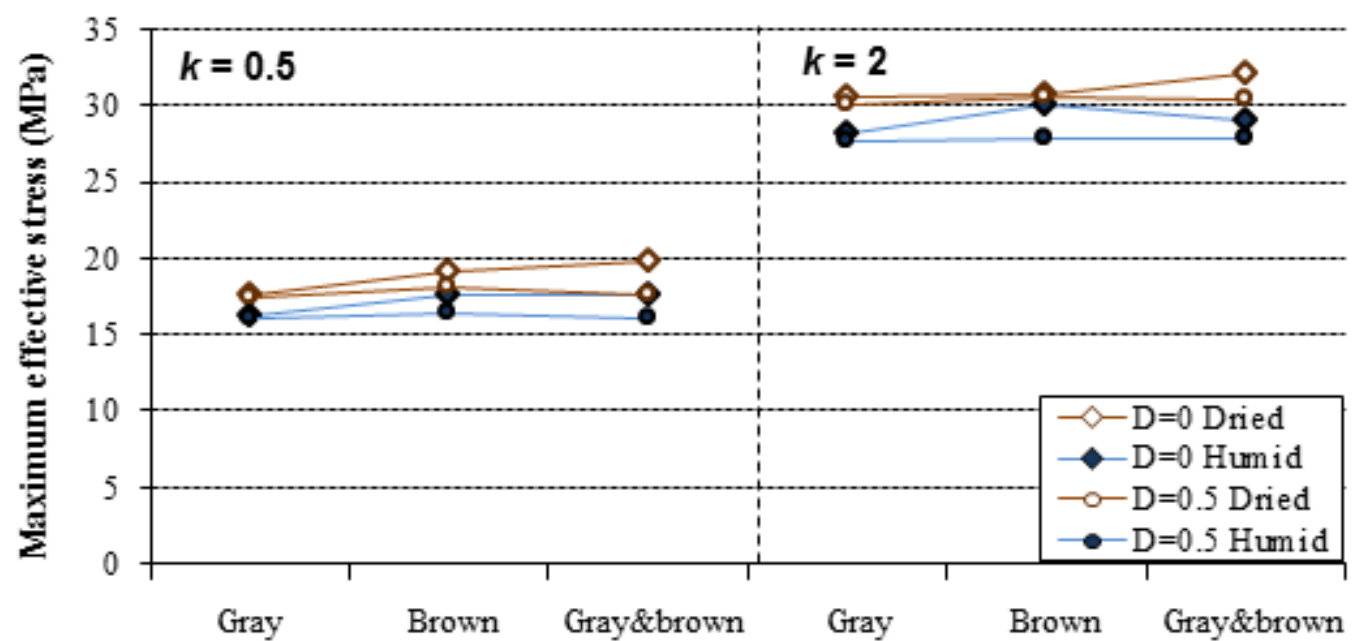

(a)

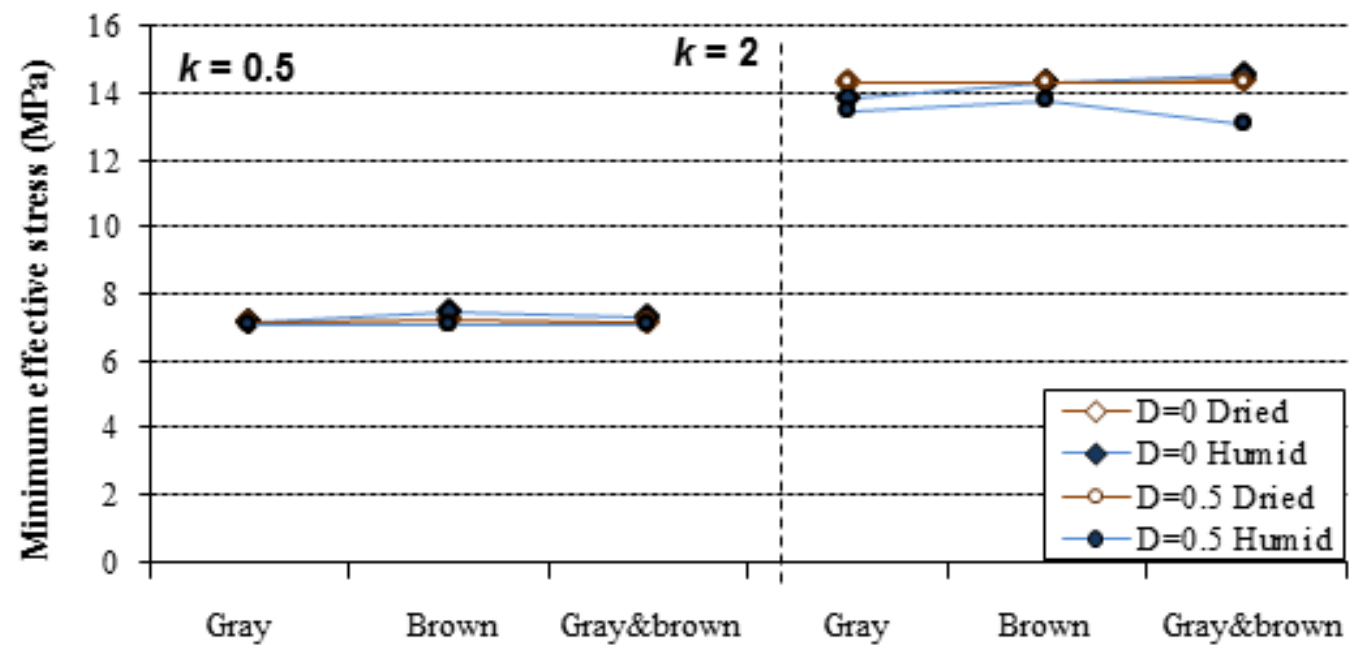

(b)

Fig. 14 Highest values of the maximum (a) and minimum (b) effective stresses around the opening according to the numerical model analyses.

As seen in Figure 15, maximum displacement values around the opening increased when the $k$ ratio was 2. Displacement in where the rock mass around the opening is a little increased, disturbed values. The biggest difference was observed between dry and moist rock masses. When the rock mass was moist, displaced values increased. Also, more displacement was observed in gray marl than in brown marl. However, in case of gray-brown marl being in the rock mass, displacement was an intermediate value more than in gray marl but less than in brown marl.

\section{CONCLUSIONS}

Prior to intact rock strength tests, it is crucial that test samples represent field conditions and especially that clayey rocks preserve their natural moisture content. According to ISRM, rock samples are suggested to be kept in certain conditions if long-term storage is necessary. However, marl samples lost their original moisture content and adapted to climate.
Samples that don't preserve their natural moisture content should be conditioned before laboratory tests. In rock material prone to fracturing like marl which is water sensitive, it is impossible to condition by water saturation. Therefore, a different way of conditioning is required. It was established that conditioning by moisture diffusion was an appropriate way of conditioning for water sensitive rock samples instead of a direct treatment with water. The marl samples have been conditioned so as to represent in situ conditions in Tunçbilek-Ömerler underground lignite mine. The optimum conditions in climate cabin for Tunçbilek marl samples were proposed to be $17.6{ }^{\circ} \mathrm{C}$ temperature and $90 \% \mathrm{RH}$. Also, it was concluded that the samples could be moisturised to the rate of $2 \%$ in this way.

In order to reveal how moisture change the strength of marl, triaxial compression tests were performed on oven dried marl samples and conditioned in $60 \%, 80 \%$ and $90 \% \mathrm{RH}$ at $17.6{ }^{\circ} \mathrm{C}$. 


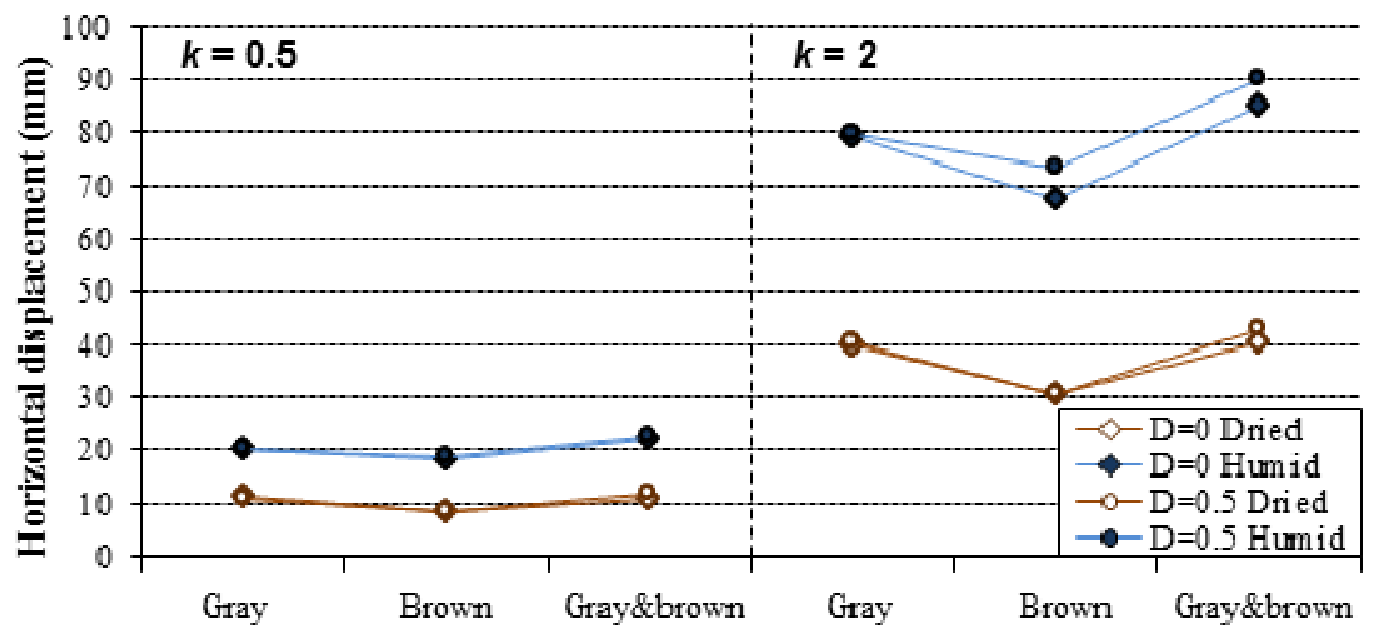

(a)

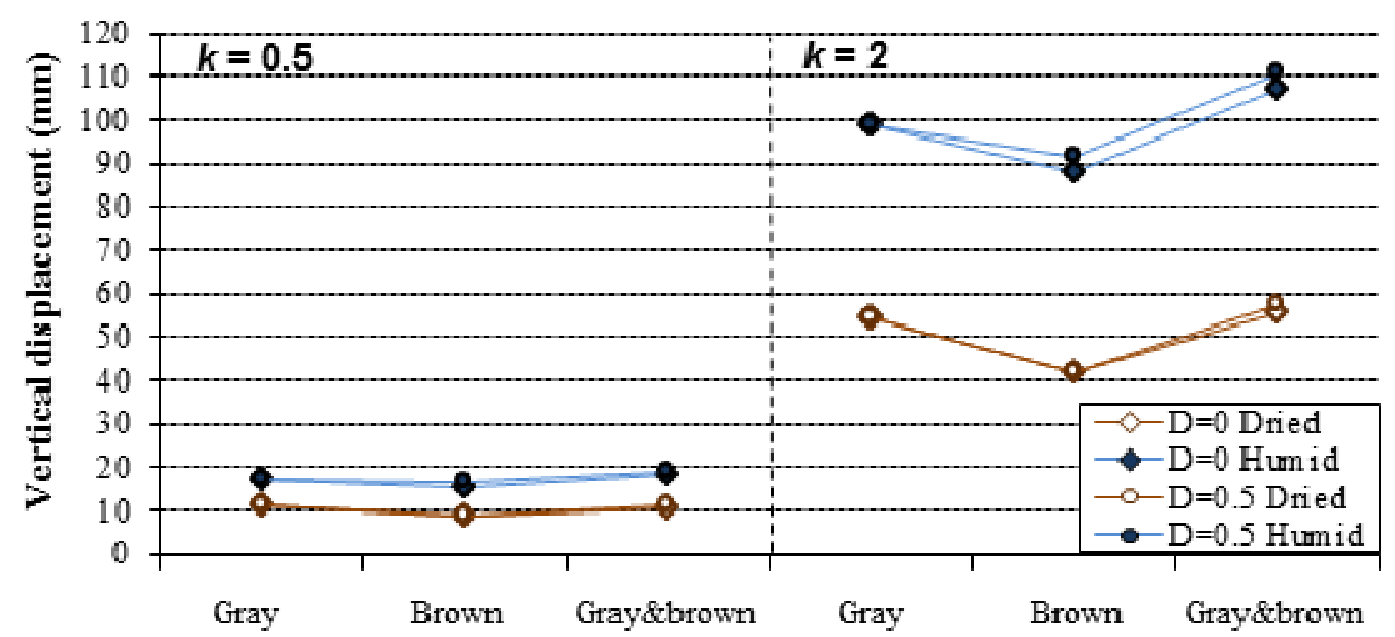

(b)

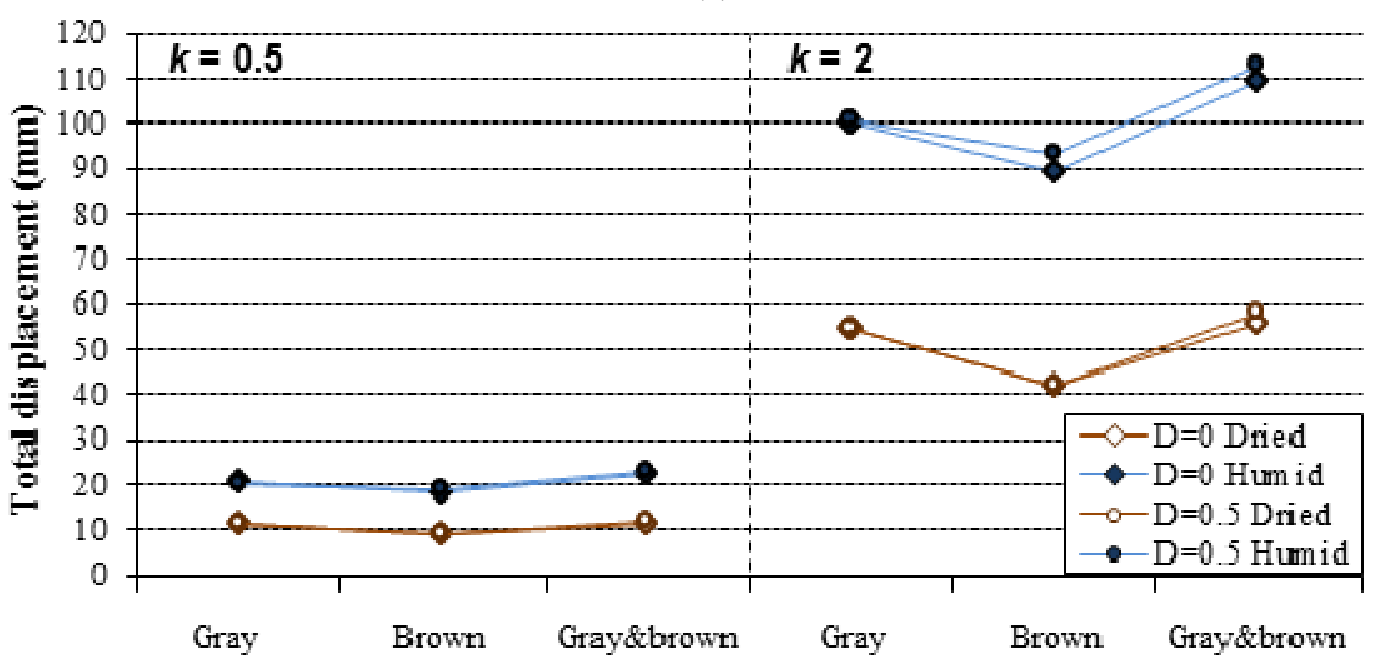

(c)

Fig. 15 Highest values of the horizontal (a), vertical (b) and total (c) displacements at the opening wall according to the numerical model analyses. 
Also; whether the color difference had an effect on the marl's strength, the samples were grouped by color as gray, brown and gray-brown sequence.

Mohr-Coulomb and Hoek-Brown failure criteria parameters for intact rock were calculated in RocLab software (2007) by using effective principal stresses found in triaxial compression tests at failure. Since the strength properties of conditioned and oven dried marl samples based on triaxial compressive test showed incomparable relationships, 24 elasto-plastic numerical models were solved by taking into account the variation of some parameters such as field stress, disturbance factor, conditioning method and rock type. Consequently, rock mass behavior was interpreted with numerical modeling based on rock material properties and after evaluating the strength of rock material according to both cohesion and internal friction angle, it was found that moisture decreased the strength of marl rock material.

Finally, the following intact rock properties are proposed for Tunçbilek marl: $33.8 \mathrm{MPa}$ for the uniaxial compression strength, 8.6 for the HoekBrown material constant, 7.1 $\mathrm{MPa}$ for the cohesion and $41^{\circ}$ for the internal friction angle for future engineering projects.

\section{ACKNOWLEDGEMENTS}

The authors wish to thank the Eskisehir Osmangazi University Academic Research Fund (project no. 200315021) for its financial support.

\section{REFERENCES}

Akkiraz, M.S., Akgün, F., Utescher T., Wilde, V., Bruch, A.A., Mosbrugger, V. and Üçbaş, S.D.: 2012, Palaeoflora and climate of lignite-bearing Lower-Middle Miocene sediments in the Seyitömer and Tunçbilek sub-basins, Kütahya Province, Northwest Turkey. Turkish J. Earth Sci., 21, 213235. DOI: $10.3906 /$ yer-1007-45

Barefield, E. and Shakoor, A.: 2006, The effect of degree of saturation on the unconfined compressive strength of selected sandstones. In: 10th IAEG International Congress, Nottingham, United Kingdom, Paper no. 606.

Basarir, H. and Karpuz, C.: 2004, A rippability classification system for marls in lignite mines. Engineering Geology, 74, 303-318.

DOI: $10.1016 /$ j.enggeo.2004.04.004

Beyhan, S.: 2008, The determination of G.L.I and E.L.I marl rock material properties depending on triaxial compressive strength. $\mathrm{PhD}$. thesis, Eskişehir Osmangazi University, Eskişehir, (in Turkish).

Birön, C. and Arıoğlu, E.: 1985, Mine support works and design, Birsen Bookstore, Istanbul, (in Turkish).

Burshtein, L.S.: 1969, Effect of moisture on the strength and deformability of sandstones. Sov. Min. Sci., 4, 573-6. DOI: 10.1007/BF02501278

Ergüler, Z.A.: 2007, Investigation of the effect of water content on engineering behavior of the clay-bearing rocks. PhD thesis, Hacettepe University, Ankara, (in Turkish).
Eskikaya, S., Biron, C. and Ugur, I.: 1991, GLI Deep Mine Project. İTÜ, İstanbul, (in Turkish).

Esmek, H., Şenkal, S. and Atakuru, N.: 1993, ÖmerlerDomaniç Deep Mine Project. GLİ Tunçbilek, Kütahya, (in Turkish).

Hawkins, A.B. and McConnell, B.J.: 1992, Sensitivity of sandstone strength and deformability to changes in moisture content. Q. J. Eng. Geol. Hydrogeol., 25(2), 115-30. DOI: 10.1144/GSL.QJEG.1992.025.02.05

Hoek, E. and Brown, E.T.: 1997, Practical estimates of rock mass strength. International Journal of Rock Mechanics and Mining Sciences, 34(8), 1165-1186. DOI: 10.1016/S1365-1609(97)80069-X

Hoek, E.: 1999, Putting numbers to geology-an engineer's viewpoint. Quarterly Journal of Engineering Geology, 32, 1-19. DOI: 10.1144/GSL.QJEG.1999.032.P1.01

ISRM: 1978a, Suggested methods for determining the strength of rock materials in triaxial compression, Int. J. Rock Mech. Min. Sci. \& Geomech., Abstr. 15, 4751.

ISRM: 1978b, Suggested methods for determining tensile strength of rock materials. Int. J. Rock Mech. Min. Sci. \& Geomech., Abstr. 15(3), 99-103.

ISRM: 1979, Suggested methods for determining the uniaxial compressive strength and deformability of rock materials. Int. J. Rock Mech. Min. Sci. \& Geomech., Abstr. 16(2), 135-140.

ISRM: 1983, Suggested methods for determining the strength of rock materials in triaxial compression:: Revised version. Int. J. Rock Mech. Min. Sci. \& Geomech., Abstr., 20(6), 285-290.

ISRM: 1989, Suggested methods for laboratory testing of argillaceous swelling rocks. Int. J. Rock Mech. Min. Sci. \& Geomech. Abstr., 26(5), 415-426.

ISRM: 2007, The complete ISRM suggested methods for rock characterization, testing and monitoring: 19742006. In: Ulusay R. \&. Hudson, J.A. (eds), Kozan Ofset, Ankara.

Kramadibrata, S., Rai, M.A., Simangunsong, G.M., Arif, I. and Setiawan, I.: 2000, The influence of water content on strength characteristic of sandstone subject to triaxial test. In: $19^{\text {th }}$ Conference on Ground Control in Mining, West Virginia, 372-377.

Kwaśniewski, M. and Rodriguez-Oitabén, P.: 2009, Effect of water on the deformability of rocks under uniaxial compression. In: Vrkljan, I. (ed) Rock Engineering in Difficult Conditions - Soft Rocks and Karst, Leiden: CRC Press/Balkema, 271-276.

Li, Z., Sheng, Y. and Reddish, D.J.: 2005. Rock strength reduction and its potential environmental consequences as a result of groundwater rebound. 9th International Mine Water Congress. Mine Closure. Oviedo, Spain, 513-519.

Lin, M.L. and Hung, J.J.: 1982, The influence of moisture content on mechanical properties of some sedimentary rocks in Taiwan. Proceeding of the 7th Southeast Asian Geotechnical Conference, 155-169.

Madsen, F.T.: 1999, Suggested methods for laboratory testing of swelling rocks. International Journal of Rock Mechanics and Mining Sciences, 36, 291-306.

Nebert, K.: 1960, Stratigraphy and tectonics of coal-bearing Neogene sediments in the west and north of Tavşanl. Bulletin of the Mineral Research and Exploration Institute (MTA) of Turkey, 54, 7-35, (in Turkish).

Phase2: 2002, Verification Manual, Rocscience Inc., Canada. 
RocLab software: 2007, version 1.031,

http://www.rocscience.com

Sachpazis, C.I.: 2004, Monitoring degree of metamorphism in a four-stage alteration process passing from pure limestone to pure marble. The Electronic Journal of Geotechnical Engineering, 9, Bundle B.

Shakoor, A. and Barefield, E.: 2009, Relationship between UCS and degree of saturation for selected sandstones. Environmental \& Engineering Geoscience, 15(1), 2940. DOI: 10.2113 /gseegeosci.15.1.29

Van Eeckhout, E.M. and Peng, S.S.: 1975, The effect of humidity on the compliances characteristics of coal mine shales. Int. J. Rock Mech. Min. Sci., 12, 335340.

Vásárhelyi, B. and Ván, P.: 2006, Influence of water content on the strength of rock. Engineering Geology, 84, 7074. DOI: 10.1016/j.enggeo.2005.11.011

Vásárhelyi, B.: 2003, Some observations regarding the strength and deformability of sandstones in case of dry and saturated conditions. Bull. Eng. Geol. Environ., 62, 245-249. DOI: 10.1007/s10064-002-0186-x

Yilmaz, I.: 2010, Influence of water content on the strength and deformability of gypsum. Int. J. Rock Mech. Min. Sci., 47, 342-347. DOI: 10.1016/j.ijrmms.2009.09.002 